Published in "Journal of Volcanology and Geothermal Research

291: 86-100, 2015"

which should be cited to refer to this work.

\title{
Eifel maars: Quantitative shape characterization of juvenile ash particles (Eifel Volcanic Field, Germany)
}

\author{
Juanita Rausch ${ }^{\mathrm{a}, *}$, Bernard Grobéty ${ }^{\mathrm{a}}$, Pierre Vonlanthen ${ }^{\mathrm{b}}$ \\ a Department of Geosciences, University of Fribourg, Chemin du Musée 6, CH-1700 Fribourg, Switzerland \\ ${ }^{\mathrm{b}}$ Institute of Earth Sciences, University of Lausanne, UNIL Mouline, Building Géopolis, CH-1015 Lausanne, Switzerland
}

\begin{abstract}
The Eifel region in western central Germany is the type locality for maar volcanism, which is classically interpreted to be the result of explosive eruptions due to shallow interaction between magma and external water (i.e. phreatomagmatic eruptions). Sedimentary structures, deposit features and particle morphology found in many maar deposits of the West Eifel Volcanic Field (WEVF), in contrast to deposits in the East Eifel Volcanic Field (EEVF), lack the diagnostic criteria of typical phreatomagmatic deposits.

The aim of this study was to determine quantitatively the shape of WEVF and EEVF maar ash particles in order to infer the governing eruption style in Eifel maar volcanoes. The quantitative shape characterization was done by analyzing fractal dimensions of particle contours (125-250 $\mu \mathrm{m}$ sieve fraction) obtained from Scanning electron microscopy (SEM) and SEM micro-computed tomography (SEM micro-CT) images.

The fractal analysis (dilation method) and the fractal spectrum technique confirmed that the WEVF and EEVF maar particles have contrasting multifractal shapes. Whereas the low small-scale dimensions of EEVF particles (Eppelsberg Green Unit) coincide with previously published values for phreatomagmatic particles, the WEVF particles (Meerfelder Maar, Pulvermaar and Ulmener Maar) have larger values indicating more complex smallscale features, which are characteristic for magmatic particles. These quantitative results are strengthening the qualitative microscopic observations, that the studied WEVF maar eruptions are rather dominated by magmatic processes. The different eruption styles in the two volcanic fields can be explained by the different geological and hydrological settings found in both regions and the different chemical compositions of the magmas.
\end{abstract}

\section{Introduction and aim of study}

The shape and internal texture of juvenile volcanic particles - especially of the fine ash fraction - provide unique insights into the fragmentation, the transport and the deposition processes, as well as the physical properties of erupted magma (e.g. magma viscosity, temperature, volatile content). In particular, the shape of volcanic particles can deliver important information on the conditions in the volcanic conduit during particle formation. Based on the morphology and texture of the juvenile clasts, the role of internal vs. external volatiles in the fragmentation processes can be evaluated (e.g. Heiken, 1972; Wohletz, 1983; Fisher and Schmincke, 1984; Dellino and La Volpe, 1995, 1996; Zimanowski et al., 1997; Büttner et al., 1999; Maria and Carey, 2002, 2007). Volatiles can either be released from the ascending magma or may be added from an external source. In the latter case, both magmatic and external water derived volatiles will be present in various proportions. Both processes may occur at a very high rate, which leads to explosive expansion of the fluid and to fragmentation of the magma. The term "magmatic"

\footnotetext{
* Corresponding author.

E-mail address: juanita.rausch@unifr.ch (J. Rausch).
}

will be used in the case where external water does not play a dominant role, whereas "phreatomagmatic" implies the interaction of external water (e.g. groundwater, seawater, surface water, etc.) with the ascending magma (see definition in Morrissey et al., 2000 in Encyclopedia of Volcanoes, page 431). The characteristics of the fragmentation products are a function of both the pre-eruptive magma properties and the fragmentation mechanism (Heiken, 1972; Schmincke, 1977; Wohletz, 1983; Fisher and Schmincke, 1984). The morphology of particles from both magmatic and phreatomagmatic eruptions have been analyzed quantitatively in the past using classical shape parameters (circularity, elongation, compactness, rectangularity, planarity, convexity, concavity, number of corners, Feret's diameter) (e.g. Honnorez and Kirst, 1975; Eiríksson et al., 1994; Dellino and La Volpe, 1996; Cioni et al., 2008). Scanning electron microscopy (SEM) based 3D morphological analysis of particles formed during different eruptive phases of the 1982-1983 Galunggung eruption (Indonesia) revealed a clear dependence of certain morphological parameters on the amount of external water involved (Ersoy et al., 2007). In a comparison study of particles from a magmatic eruption of Katla and a phreatomagmatic eruption of Grimsvötn (both in Iceland) clear differences of the particle shapes and surfaces - especially at small scales - were also found (Maria and Carey, 2002). 
The Eifel Volcanic Field (EVF) (Germany) is the type of locality for maar volcanism. Maar volcanoes have been classically interpreted as the result of explosive water-magma interaction (i.e. phreatomagmatic eruptions) (e.g. Steininger, 1820; Fisher and Waters, 1970; Nakamura and Krämer, 1970; Waters and Fisher, 1971; Crowe and Fisher, 1973; Lorenz, 1973; Schmincke et al., 1973; Schmincke, 1977). However, while most deposits of East Eifel maars seem to have all the characteristics of typical phreatomagmatic products, most of them are lacking in the West Eifel maar deposits. In addition, features incompatible with a phreatomagmatic origin but typical for magmatic eruptions (e.g. agglutinated particles) are very common in the West Eifel (Schmincke, 2007; Rausch, 2014). In the present work we want to test if the differences between East and West Eifel maar deposits are also present in the morphology of juvenile particles.

The morphology analysis of the maar juvenile particles from both volcanic fields was made using the fractal method. Fractal dimensions have been introduced by Mandelbrot (1967). This method measures the self-similarity of a shape at different scales. True fractal objects are characterized by a single fractal dimension valid for all scales. Non- or pseudo fractal objects can nevertheless also be analyzed by the fractal method. Such objects are characterized by several fractal dimensions, each of which is valid for a specific scale range. Fractal analysis has since then been applied on a wide range of complex objects, including small unspecified particles (Kaye, 1978), biological cells (Baumann et al., 1994), aerosols (Kindratenko et al., 1994) and marine snow (Kilps et al., 1994). Fractal dimensions have also been used in many fields of geosciences such as remote sensing (Sun et al., 2006), geomorphology (Dodds and Rothman, 2000) and geophysics (Lovejoy and Schertzer, 2007). A number of applications of the fractal method to volcanic deposits (e.g. Kueppers et al., 2006; Perugini et al., 2007, 2011; Pepe et al., 2008) and particles (e.g. Orford and Whalley, 1983; Carey et al., 2000; Maria and Carey, 2002, 2007; Dellino and Liotino, 2002; Mattsson, 2010) have proven the great potential of this method when studying volcanic processes.

Volcanic particles are characterized by pseudofractal geometries. Different self-similarities are observed for small and large scales, which are described by two fractal dimensions (D1 and D2). D1, called the textural fractal dimension by Maria and Carey (2002, 2007), describes the self-similarity at small scales, whereas D2 is the morphological fractal dimension, which describes the self-similarity at large scales. The latter authors demonstrated that the two fractal dimensions were characteristic for the eruption type which produced the particles. They were able to discriminate between particles emitted from recent phreatomagmatic (Grimsvötn, Iceland) and magmatic (Katla, Iceland) eruptions. In the present work we compared the values obtained by Maria and Carey with the fractal dimensions obtained from the Eifel maar particles.

\section{Geological setting}

The Eifel Volcanic Field (EVF) is located in western central Germany $\sim 40 \mathrm{~km}$ south of Bonn. It is subdivided into three fields: the West, East and Hoch Eifel Volcanic Fields (WEVF, EEVF and HEVF) (Mertes and Schmincke, 1985; Schmincke, 2007) (Fig. 1, inset map). The EVF developed on the Rhenish shield, a large Paleozoic block that has been uplifted during the past $40 \mathrm{Ma}$ and that is in part still rising (e.g. Fuchs et al., 1983). The Eifel volcanism started in the Hocheifel during the Eocene about $50 \mathrm{Ma}$ ago, while the volcanic activity in the West Eifel started at $\sim 700-600 \mathrm{ka}$ and in the East Eifel at $460 \mathrm{ka}$ (Schmincke, 2007). The most recent activity occurred at Ulmener Maar (West Eifel) 11,000 a BP (Zolitschka et al., 1995; Sirocko et al., 2013). The WEVF $\left(\sim 600 \mathrm{~km}^{2}\right)$ is limited by the Booser maars to the northeast, the towns of Bad Bertrich to the south, and Ormont to the northwest. The WEVF consists of $~ 240$ volcanic centers ( 6 maar lakes, 70 "dry" maar craters and 160 scoria cones) (Büchel and Mertes, 1982; Büchel, 1994). The EEVF $\left(\sim 400 \mathrm{~km}^{2}\right)$ is bordered by the Rhine River to the east, the Moselle River to the southeast, and the towns of Mayen to the south and Kempenich to the west. It comprises about 100 volcanic centers ( $~ 80$ scoria cones, a few well-preserved maars and several larger phonolitic volcanic complexes such as Kempenich, Rieden, Wehr and Laacher See) (Schmincke, 2007) (Fig. 1). Both fields are NW-SE oriented coinciding with the preferential orientation of dikes and faults, which served as pathways for rising magmas (Mertes and Schmincke, 1985; Schmincke, 2007).

The 4-6 km thick West Eifel basement consists of folded Lower Devonian non-porous, clastic, sedimentary rocks (sandstone, siltstone, graywacke and slate) (Meyer, 2013), deposited during the stages Siegen (Pragian) and Ems (Meyer and Stets, 1979). The Lower Devonian rocks are overlain in the central part of the field by Middle to Upper Devonian limestones and in the western part of the WEVF by lower Triassic Buntsandstein sandstones (Meyer and Stets, 1979; Büchel, 1994). In the East Eifel, the Lower Devonian rocks are overlain by up to $25 \mathrm{~m}$ thick, impermeable Tertiary clay deposits with local intercalations of unconsolidated, highly permeable sand and gravel (Meyer, 2013).

\section{Studied deposits}

Juvenile particles from three maar deposits in the WEVF and from one maar phase in the EEVF were studied. The general stratigraphy, sedimentology and volcanology of each single maar deposit are summarized in Appendix A.

\subsection{West Eifel}

\subsubsection{Meerfelder Maar (MFM)}

The age of Meerfelder Maar, the largest maar in the West Eifel Volcanic Field, is still a matter of debate and ranges from $\sim 45,000$ a BP $\left({ }^{14} \mathrm{C}\right.$ dating, Schaber and Sirocko, 2005; Schmincke, 2009, 2014) to $80,400 \pm 8340$ (feldspar infrared stimulated luminescence, Zöller et al., 2009).

The up to $23 \mathrm{~m}$ thick MFM deposit is well exposed in the Leyendecker pit, 400 m southeast of the town Deudesfeld and $400 \mathrm{~m}$ west of the MFM crater rim (Appendix A), representing a proximal to medial facies of the deposit. The MFM deposit was subdivided into five depositional units (I-V) (Appendix A). The particles analyzed were selected from the MFM03 layer in Unit I, the MFM07 layer in Unit II, the MFM20 layer in Unit III, and the MFM40, MFM45 and MFM49 layers in Unit V. The selected layers differ by their transport and deposition mode. Particles from fallout, surge and debris jet layers have been analyzed. The description of the layers is shown in Table 1.

\subsubsection{Pulvermaar (PM)}

The Pulvermaar eruption is estimated at 15,000-20,000 a BP (Büchel and Lorenz, 1982; Büchel, 1993) based on the occurrence of ice wedges at the base of the tephra ring deposit, which are interpreted to be from the last glacial period (Weichsel). The PM deposit, which crops out in a pit 300 m east of the town of Gillenfeld, on the southwestern rim of the Pulvermaar crater (Appendix A), represents a proximal facies of the eruption. Here, the deposit has a minimum thickness of $27 \mathrm{~m}$, whereby only the uppermost $14 \mathrm{~m}$ are exposed. The PM deposit was subdivided into five stratigraphic units (I-V) (Appendix A). The particles analyzed were picked from the PM22 and PM25 layers in Unit I (Table 1).

\subsubsection{Ulmener Maar (UM)}

The Ulmener Maar is the result of the youngest eruption in Germany (11,000 a BP) according to calibrated ${ }^{14} \mathrm{C}$ dating (Sirocko et al., 2013) and corrected varve chronology (Zolitschka et al., 1995). The up to $7.5 \mathrm{~m}$ thick deposit was logged on the western rim of the UM crater, in a road cut along the Cochemer Strasse north of the church of Ulmen, $80 \mathrm{~m}$ south of highway A48 (Appendix A). This section represents the proximal facies of the Ulmener Maar eruption, which was subdivided into nine depositional units (I-IX) based on lithological, 


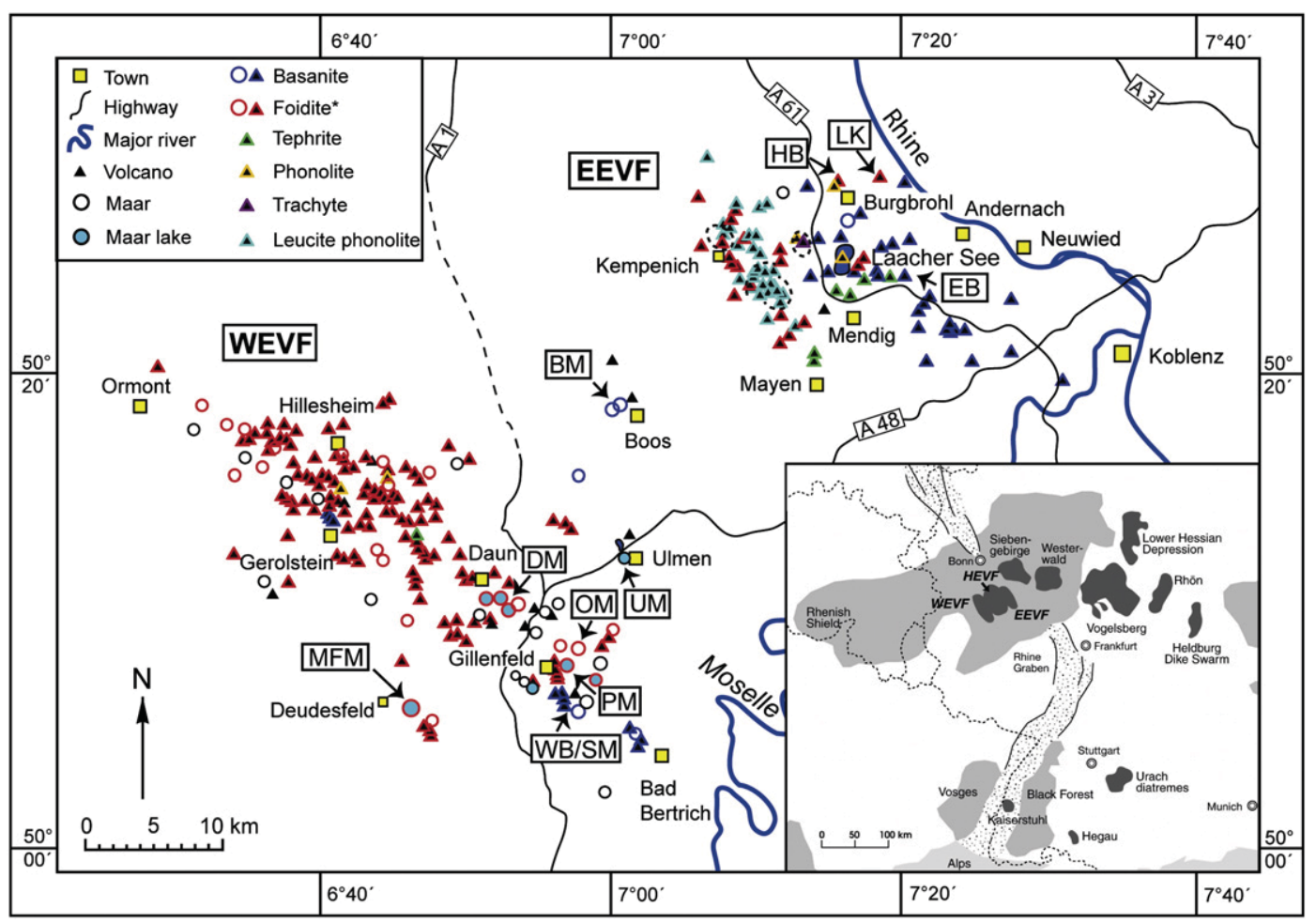

Fig. 1. Map of the Eifel Volcanic Field (Germany), showing the West and East Eifel Volcanic Fields (WEVF and EEVF) and the best exposed maar volcanoes. MFM: Meerfelder Maar, DM: Dauner Maars, PM: Pulvermaar, OM: Oberwinkler Maar, WB/SM: Wartgesberg/Sprinker Maar, UM: Ulmener Maar, BM: Booser Maars, HB: Herchenberg, LK: Leilenkopf, and EB: Eppelsberg. Chemical rock compositions for the volcanoes (see legend) are from Mertes and Schmincke (1985) and Schmincke (2007). Inset map: Cenozoic volcanic fields located on the uplifted Rhenish shield and close-by areas. The Eifel Volcanic Fields, i.e. the Quaternary WEVF and EEVF as well as the Eocene Hocheifel Volcanic Field (HEVF) are located in western Germany, south of Bonn. Dashed lines are for national borders.

Modified from Büchel and Mertes (1982) and Schmincke (2007).

grain size and sedimentological changes (Appendix A). The particles analyzed were selected from the UM01 and UM03 layers in Unit I (Table 1).

\subsection{East Eifel}

\subsubsection{Eppelsberg}

Eppelsberg is a highly complex scoria cone volcano cropping out $\sim 2 \mathrm{~km}$ east of Laacher See and $\sim 2 \mathrm{~km}$ north of highway A61 (Appendix A). The outcrop consists of several eruptive phases highly variable in nature, ranging from proximal to distal scoria cone deposits to wellbedded maar phases separated occasionally by paleosols and reworked loess deposits. The complex deposit succession is topped by Laacher See Tephra (12,900 a BP, van den Bogaard, 1995) and is estimated to have been erupted 150,000-250,000 a BP. In this study, we focused on one of the well-bedded, fine-grained maar phases, referred to as the Eppelsberg Green Unit (EBGU), which was stratigraphically subdivided into four units (I-IV) (Appendix A). The juvenile particles analyzed were extracted from the EBGU03 and EBGU04 layers from Unit II (Table 1).

\section{Methodology}

\subsection{Light microscopy}

One hundred and fifty thin sections of lapilli to coarse ash-sized particles from the four studied maar deposits were analyzed by light microscopy. The descriptive morphology (i.e. angular, round, subround), the different constituents (i.e. phenocrysts, xenolith and lithoclast inclusions, groundmass and vesicles) and the internal texture (agglutination, composite lapilli) of the juvenile particles were determined (Table 1).

\subsection{Scanning electron microscopy (SEM)}

Juvenile particles of the $125-250 \mu \mathrm{m}$ sieve fraction were separated from the deposits of all four studied maars, mounted in epoxy resin, and polished down as thin sections. This sieve fraction was used because it enabled a direct comparison with the fractal analyses performed by Maria and Carey (2002) on either type of particle end-members (magmatic and phreatomagmatic).

The thin sections were analyzed with an automated SEM- and energy dispersive spectroscopy (EDS)-based single particle analysis routine. The analyses were performed using the FEI XL30 Sirion field-emission (FE) SEM of the University of Fribourg (Switzerland), operated at an acceleration voltage of $25 \mathrm{kV}$. Contours of individual particles were extracted from electron backscattered (BSE) images for subsequent fractal analysis. The images $(1280 \times 960$ pixels $)$ were taken with a magnification of $200 \times$.

\subsection{SEM micro-CT}

High-resolution 3D reconstructions of 17 juvenile particles of the same sieve fraction (125-250 $\mu \mathrm{m}$ ) were obtained by scanning electron microscopy X-ray micro-computed tomography (SEM micro-CT) at the University of Lausanne (Switzerland) using a CamScan MV2300 SEM equipped with a Bruker SEM micro-CT attachment. This technique enables visualization and morphometric quantification with micron to sub-micron resolution of small-scale 3D features, such as vesicles. The reconstructed volume can be sectioned along all orientations and positions within a single particle. Contours of such cross-sections were analyzed by fractal analysis. All images obtained from the SEM micro-CT analyses had a pixel dimension of $512 \times 512$. A detailed description of 
Table 1

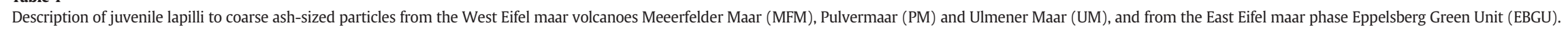

\begin{tabular}{|c|c|c|c|c|c|c|c|c|c|c|c|c|}
\hline \multirow[t]{2}{*}{ Locality } & \multirow[t]{2}{*}{ Sample } & \multirow[t]{2}{*}{ Description of layer } & \multirow[t]{2}{*}{ Composition } & \multicolumn{9}{|c|}{ Description of juvenile lapilli } \\
\hline & & & & Morphology & Texture & Groundmass & Vesicularity & $\begin{array}{l}\text { Vesicle } \\
\text { shape }\end{array}$ & Phenocrysts & $\begin{array}{l}\text { Xenolith } \\
\text { inclusions }\end{array}$ & $\begin{array}{l}\text { Lithoclast } \\
\text { inclusions }\end{array}$ & Other features \\
\hline \multirow{10}{*}{$\begin{array}{l}\text { West Eifel } \\
\text { Meerfelder } \\
\text { Maar } \\
50^{\circ} 06^{\prime} 03.00^{\prime \prime} \mathrm{N} \\
06^{\circ} 44^{\prime} 20.46^{\prime \prime} \mathrm{E}\end{array}$} & MFM03 & $\begin{array}{l}\text { Well-sorted, lapilli-sized, } \\
\text { black scoria lapilli fallout }\end{array}$ & \multirow{6}{*}{$\begin{array}{l}\text { Melilite-bearing } \\
\text { olivine } \\
\text { nephelinite }\end{array}$} & Highly irregular & Smooth & $\begin{array}{l}\text { Mainly } \\
\text { sideromelane }\end{array}$ & $\begin{array}{l}\text { Moderate to } \\
\text { high }(40-70 \%)\end{array}$ & $\begin{array}{l}\text { Round, } \\
\text { connected }\end{array}$ & Cpx, ol & No & $\begin{array}{l}\text { Sandstone, } \\
\text { slate }(<5 \%)\end{array}$ & Composite lapilli type $1^{\mathrm{a}}$ \\
\hline & MFM07 & $\begin{array}{l}\text { Crudely bedded, coarse } \\
\text { grained, lithic-rich (debris } \\
\text { jet) }\end{array}$ & & Subround & $\begin{array}{l}\text { Highly } \\
\text { rugose }\end{array}$ & Tachylitic & $\begin{array}{l}\text { Relatively low } \\
(10-20 \%)\end{array}$ & Irregular & Cpx, ol & Peridotite & $\begin{array}{l}\text { Sandstone, } \\
\text { slate (15-20\%) }\end{array}$ & Composite lapilli type $2^{\mathrm{b}}$ \\
\hline & MFM20 & $\begin{array}{l}\text { Lithic-rich, coarsest } \\
\text { grained layer (blocks }<1 \mathrm{~m} \\
\text { ø) (debris jet) }\end{array}$ & & Subround & $\begin{array}{l}\text { Highly } \\
\text { rugose }\end{array}$ & Tachylitic & $\begin{array}{l}\text { Relatively low } \\
(10-20 \%)\end{array}$ & Irregular & Cpx, ol & Peridotite & $\begin{array}{l}\text { Sandstone, } \\
\text { slate (15-20\%) }\end{array}$ & Composite lapilli type $2^{\mathrm{b}}$ \\
\hline & MFM40 & $\begin{array}{l}\text { Moderately sorted, } \\
\text { lapilli-sized fallout. } \\
\text { Relatively juvenile rich }\end{array}$ & & Subround & $\begin{array}{l}\text { Highly } \\
\text { rugose }\end{array}$ & Tachylitic & $\begin{array}{l}\text { Low to } \\
\text { moderate } \\
(10-40 \%)\end{array}$ & Subround & Cpx, ol & Peridotite & $\begin{array}{l}\text { Sandstone, } \\
\text { slate (15-20\%) }\end{array}$ & Composite lapilli type $2^{\mathrm{b}}$ \\
\hline & MFM45 & $\begin{array}{l}\text { Grayish, moderately to } \\
\text { well-sorted, juvenile-rich } \\
\text { fallout }\end{array}$ & & Subround & $\begin{array}{l}\text { Highly } \\
\text { rugose }\end{array}$ & Tachylitic & $\begin{array}{l}\text { Low to } \\
\text { moderate } \\
(10-30 \%)\end{array}$ & $\begin{array}{l}\text { Subround to } \\
\text { irregular }\end{array}$ & Cpx, ol & Peridotite & $\begin{array}{l}\text { Sandstone, } \\
\text { slate (15-30\%) }\end{array}$ & Composite lapilli type $2^{\mathrm{b}}$ \\
\hline & MFM49 & $\begin{array}{l}\text { Grayish, juvenile-rich, fine } \\
\text { lapilli-sized, well-sorted } \\
\text { fallout }\end{array}$ & & Irregular & $\begin{array}{l}\text { Slightly } \\
\text { rugose }\end{array}$ & $\begin{array}{l}\text { Mainly } \\
\text { sideromelane }\end{array}$ & $\begin{array}{l}\text { Moderate to } \\
\text { high }(40-70 \%)\end{array}$ & $\begin{array}{l}\text { Round, } \\
\text { connected }\end{array}$ & Cpx, ol & Peridotite & $\begin{array}{l}\text { Sandstone, } \\
\text { slate }(<5 \%)\end{array}$ & \\
\hline & PM22 & $\begin{array}{l}\text { Coarse ash to lapilli-sized, } \\
\text { moderately-sorted (debris } \\
\text { jet) }\end{array}$ & \multirow[t]{2}{*}{$\begin{array}{l}\text { Melilite } \\
\text { nephelinite }\end{array}$} & Subround & $\begin{array}{l}\text { Highly } \\
\text { rugose }\end{array}$ & Tachylitic & $\begin{array}{l}\text { Relatively low } \\
(10-20 \%)\end{array}$ & $\begin{array}{l}\text { Subround to } \\
\text { irregular }\end{array}$ & $\begin{array}{l}\text { Cpx, } \\
\text { ol } \pm \text { amp }\end{array}$ & $\begin{array}{l}\text { Cumulate }{ }^{\mathrm{c}} \text {, } \\
\text { granite } \pm \\
\text { peridotite }\end{array}$ & $\begin{array}{l}\text { Sandstone, } \\
\text { slate (10-15\%) }\end{array}$ & Composite lapilli type $2^{\mathrm{b}}$ \\
\hline & PM25 & $\begin{array}{l}\text { Fine-grained (ash-sized), } \\
\text { cross-bedded deposit } \\
\text { (surge) }\end{array}$ & & Subround & $\begin{array}{l}\text { Highly } \\
\text { rugose }\end{array}$ & Tachylitic & $\begin{array}{l}\text { Relatively low } \\
(10-20 \%)\end{array}$ & $\begin{array}{l}\text { Subround to } \\
\text { irregular }\end{array}$ & $\begin{array}{l}\text { Cpx, } \\
\text { ol } \pm \text { amp }\end{array}$ & $\begin{array}{l}\text { Cumulate }{ }^{c} \text {, } \\
\text { granite }\end{array}$ & $\begin{array}{l}\text { Sandstone, } \\
\text { slate (10-15\%) }\end{array}$ & Composite lapilli type $2^{\mathrm{b}}$ \\
\hline & UM01 & $\begin{array}{l}\text { Lapilli-sized, } \\
\text { moderately-sorted, } \\
\text { lithic-rich (debris jet) }\end{array}$ & \multirow[t]{3}{*}{$\begin{array}{l}\text { Melilite } \\
\text { nephelinite }\end{array}$} & Round/subround & Rugose & Tachylitic & $\begin{array}{l}\text { Relatively low } \\
(10-20 \%)\end{array}$ & $\begin{array}{l}\text { Subround to } \\
\text { irregular }\end{array}$ & $\begin{array}{l}\text { Cpx, ol, ne, } \\
\text { mel }\end{array}$ & No & $\begin{array}{l}\text { Sandstone, } \\
\text { slate (5-25\%) }\end{array}$ & $\begin{array}{l}\text { Composite lapilli type } 2^{\mathrm{b}} \text {, } \\
\text { fine-grained coating }\end{array}$ \\
\hline & UM03 & $\begin{array}{l}\text { Lapilli/ash-sized, } \\
\text { well-sorted, slightly more } \\
\text { juvenile-rich (fallout) }\end{array}$ & & Round/subround & Rugose & Tachylitic & $\begin{array}{l}\text { Relatively low } \\
(10-20 \%)\end{array}$ & $\begin{array}{l}\text { Subround to } \\
\text { Irregular }\end{array}$ & $\begin{array}{l}\text { Cpx, ol, ne, } \\
\text { mel }\end{array}$ & No & $\begin{array}{l}\text { Sandstone, } \\
\text { slate (5-25\%) }\end{array}$ & $\begin{array}{l}\text { Composite lapilli type } 2^{\mathrm{b}} \text {, } \\
\text { fine-grained coating }\end{array}$ \\
\hline \multirow{3}{*}{$\begin{array}{l}\text { East Eifel } \\
\text { Eppelsberg } \\
50^{\circ} 24^{\prime} 09.13^{\prime \prime} \mathrm{N} \\
07^{\circ} 19^{\prime} 11.52^{\prime \prime} \mathrm{E}\end{array}$} & & & & & & & & & & & & \\
\hline & EBGU03 & $\begin{array}{l}\text { Brownish, ash-sized, finely } \\
\text { bedded deposit (wet } \\
\text { fallout) }\end{array}$ & \multirow[t]{2}{*}{ Basanite } & Angular & Smooth & Sideromelane & $\begin{array}{l}\text { Very low } \\
(0-15 \%)\end{array}$ & Round & $\begin{array}{l}\text { Cpx } \pm \text { ol, } \\
\text { amp, bt }\end{array}$ & No & No & $\begin{array}{l}\text { Accretionary/armored lapilli, } \\
\text { fine-grained coating }\end{array}$ \\
\hline & EBGU04 & $\begin{array}{l}\text { Greenish, ash-sized, finely } \\
\text { bedded deposit (wet } \\
\text { fallout) }\end{array}$ & & Angular & Smooth & Sideromelane & $\begin{array}{l}\text { Very low } \\
(0-15 \%)\end{array}$ & Round & $\begin{array}{l}\text { Cpx } \pm \text { ol, } \\
\text { amp, bt }\end{array}$ & No & No & $\begin{array}{l}\text { Accretionary/armored lapilli, } \\
\text { fine-grained coating }\end{array}$ \\
\hline
\end{tabular}

${ }^{a}$ Lapilli composed of dark tachylitic, dense to moderate vesiculated particles embedded in a glassy (sideromelane), high to moderate vesiculated groundmass.

b Lapilli consisting of dark, dense, tachylitic patches or droplets and slightly lighter tachylitic higher vesiculated (up to 40\%) areas.

c Cumulates consisting of clinopyroxene (Cpx), amphibole (amp) and biotite (bt). 
the SEM micro-CT technique and its applicability to volcanic ash is presented in Vonlanthen et al. (2014).

\subsection{Fractal analyses}

The mathematician Benoit Mandelbrot (1967) coined the term fractal for objects (or mathematic functions) for which the shape of the contours was scale-independent, i.e. had similar shape independent of the scale at which the object/function was observed. He discovered that many natural contours such as coast lines, leave rims and river networks are fractal in nature. The strength of fractal analysis developed by Mandelbrot is its ability to describe in simple manner complex objects, which were very difficult or impossible to handle by Euclidean geometry. The fractal nature of a contour can be tested by measuring its length with ever-decreasing yard stick lengths $s$ (= scale). The length $L$ of a fractal line (fractal surface, volume) measured at a scale $s$ is given by ( $k$ : constant):

$L=k s^{-D}$.

The exponent $D$ for a true fractal object, called the fractal dimension or Hausdorff dimension, is constant and independent of $s$. Graphically the fractal dimension can be extracted from the slope of Richardson plots $\log (L)$ vs. $\log (s)$.

Many objects and time series in nature (e.g. human heart beat, natural luminosity or meteorology time series) are pseudo- or multifractal, i.e. they cannot be described by a single Hausdorff dimension, but by several exponents, each valid only for a limited scale range, or by a continuous spectrum of changing exponents, called singularity spectrum. Fractal analysis of object contours is mostly done on digital images of the objects of interest. Such images are limited in resolution by the pixel size and the magnification at which the images were taken. Pixel based images of contours are strictly speaking never truly fractal in nature, because the scale of observation cannot be reduced infinitely but is limited by the pixel size. Nevertheless the method is applied to pixelate lines, stopping at the scale of the pixel size. Volcanic particles turned out to be multifractal and can be described by two fractal dimensions (D1 and D2).

The advantage of fractal analysis is that it gives morphological information of contours for different scales. Many classic shape descriptors (e.g. excentricity) only give information on the large-scale characteristics of a contour, whereas others such as circularity, convexity, rectangularity or solidity are more sensitive to small scale features. In both cases, however, no information can be retrieved for a specific scale of interest. Individual contour curvature plots, area functions or triangle area representations are shape descriptors corresponding to only one specific scale. To ensure a multiscale description, a set of descriptor curves, or a combination of different types of descriptors are necessary.

The fractal spectra belong to descriptors which contain multiscale information on a contour within one single curve (function), which is a clear advantage over the previously mentioned descriptors. Similar multiscale descriptors are the curvature scale space or the chord length and angle distributions.

For the fractal analyses, BSE and SEM micro-CT grayscale images of individual particle sections were converted to binary images, and subsequently the particle outline, one pixel in width, was extracted (Fig. 2, steps 1-4) using the image processing software Image (http://imagej. nih.gov/ij/). The images obtained through SEM micro-CT were smoothed to eliminate artifacts such as the spurious spikes present at some corners of the cross sections. Smoothing reduces the resolution of the contour. Therefore, a relatively low Gaussian smoothing value ( $S=2$ in the Bruker's NRecon software, see Vonlanthen et al., 2014 for details) was applied. This value turned out to have little effect on

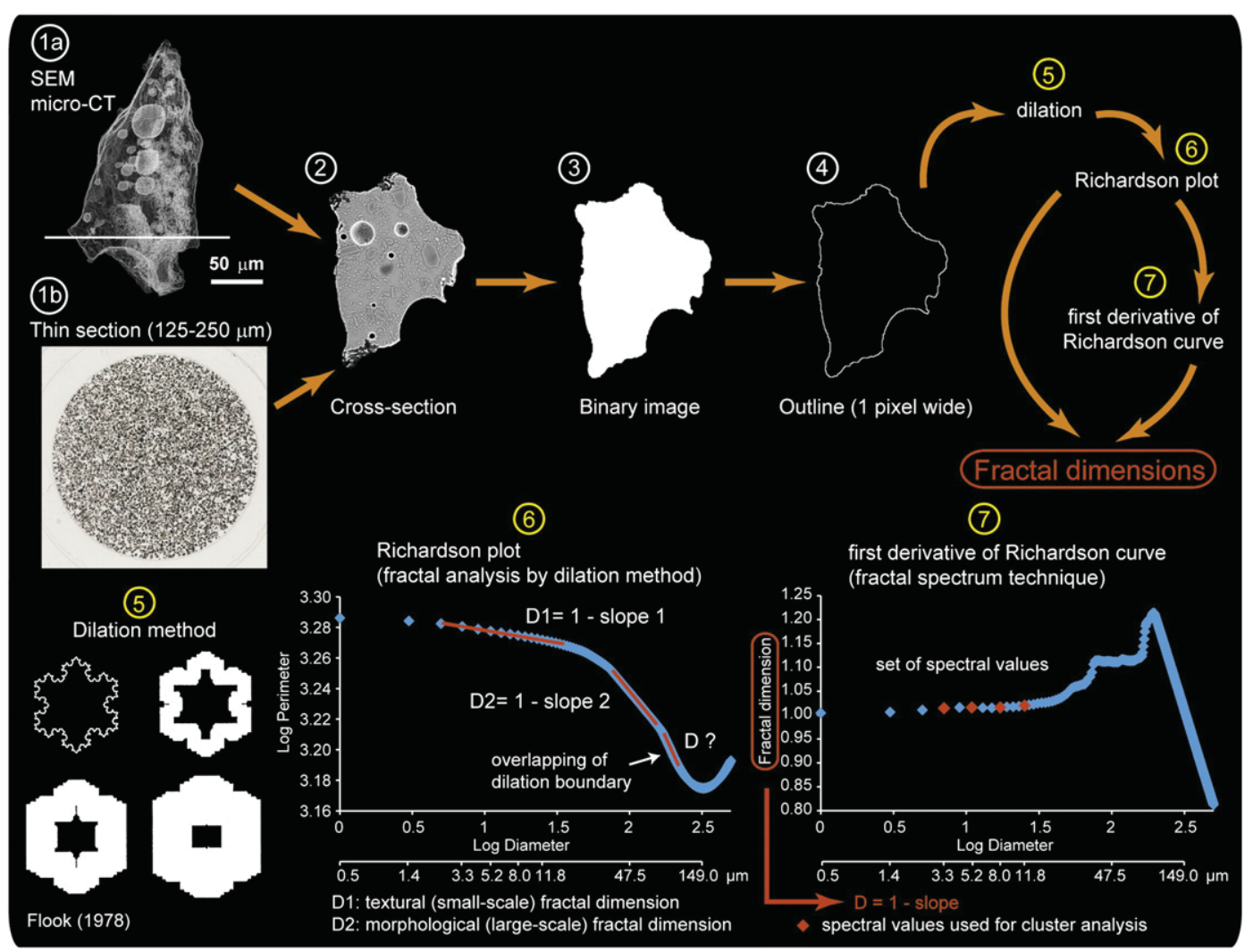

Fig. 2. Processing steps for the fractal analysis by the dilation method (steps 1-6) and by the fractal spectrum technique (steps 1-7). 


\section{Test: Different degrees of smoothing}
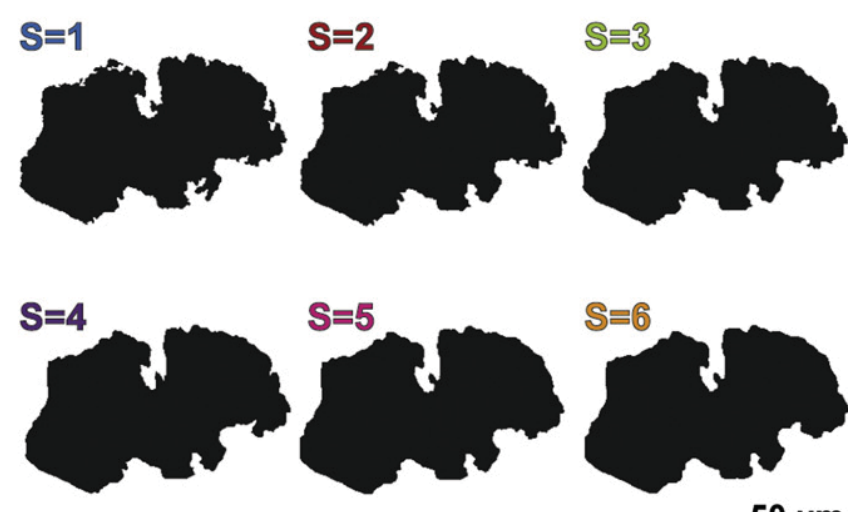

$50 \mu \mathrm{m}$
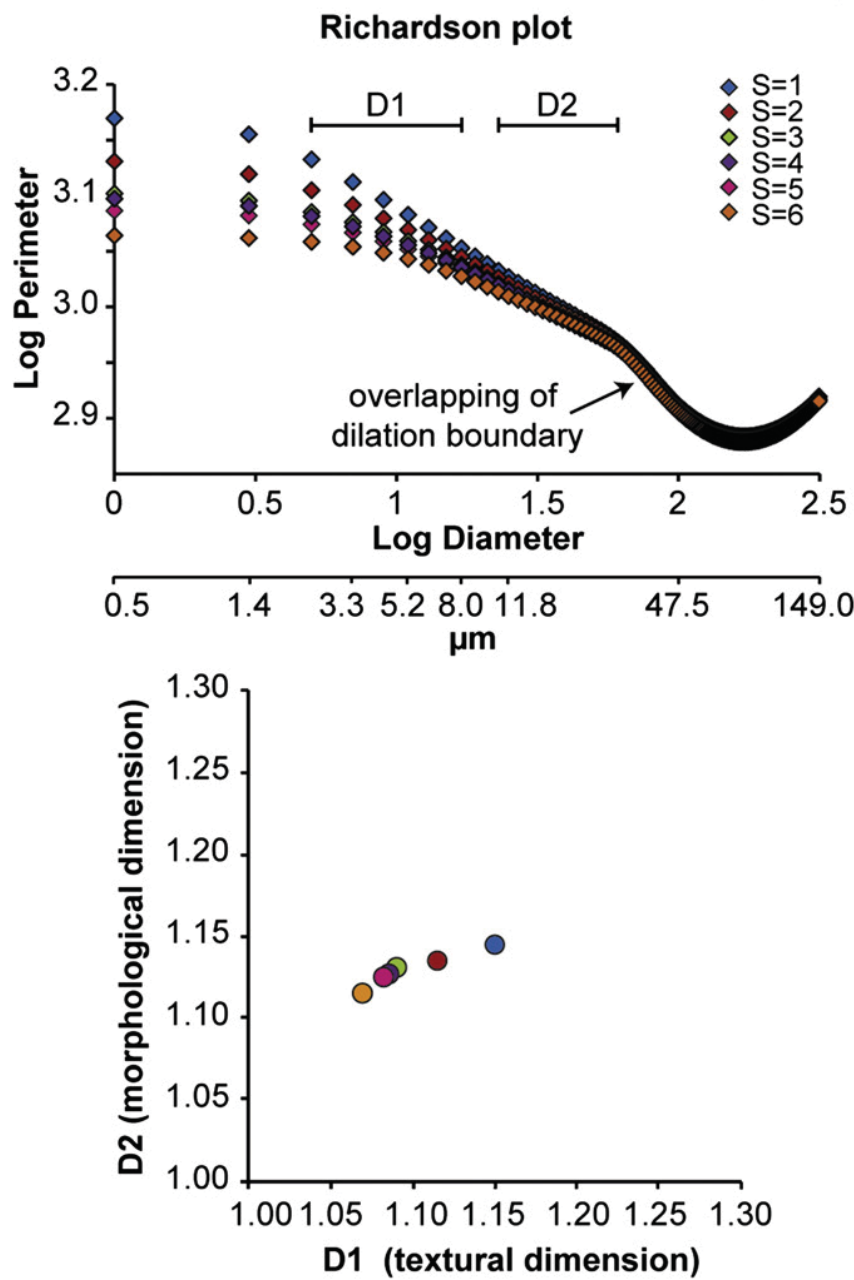

Fig. 3. Test of the influence of the degree of smoothing $(S=1-S=6)$ on fractal dimensions calculated for an SEM micro-CT slice of sample MFM45-4 (for details see Vonlanthen et al., 2014).

$\mathrm{D} 1(\mathrm{D} 1=1.150$ for $\mathrm{S}=1$ and $\mathrm{D} 1=1.113$ for $\mathrm{S}=2$ ) and minimal on $\mathrm{D} 2$ (D2 = 1.146 for $S=1$ and $D 2=1.135$ for $S=2$ ), but it is nevertheless sufficient to eliminate the artifacts (Fig. 3, Appendix B).

For the calculation of the fractal dimensions the dilation method (Fig. 2, step 5) was preferred among the different fractal techniques at disposal (e.g. caliper and box counting methods) because of its simplicity and lower susceptibility to pixelization effects (Smith et al., 1989, 1996; Maria and Carey, 2002). The principle of the dilation method is that the single-pixel particle outline is progressively widened (and thus, smoothened) in steps of one pixel at each side of the outline not occupied by a pixel. The smallest scale is, therefore, equal to the pixel dimension ( $=0.47 \mu \mathrm{m}$ for all studied images) and the width of the line (=scale) increases by 2 pixels at each widening step (i.e. successive line width: 1, 3, 5, 7 pixels and so on). At each dilation step the area of the particle outline is measured. At large scales, widened contours of opposite sides of the particle start to overlap and give erroneous contour areas. The upper limit depends on the dimensions of the actual contour. For the smallest particles analyzed $(125 \mu \mathrm{m} ø)$ this value is around $62.5 \mu \mathrm{m}$, while for the largest particles $(250 \mu \mathrm{m} ø)$ the overlapping starts at around $125 \mu \mathrm{m}$ contour width. The length $(\mathrm{L})$ or perimeter $(\mathrm{P})$ of the particle outline at each single dilation step is calculated by dividing the area of the dilated outline by the width of the outline. The dilation process was performed using Adobe Photoshop. A macro was created enabling the fast application of the technique to a large number of particles (few minutes per particle). Within the limits set by pixel size and overlapping problems, most of the resulting Richardson plots can be described by two linear segments with slopes corresponding to the small-scale "textural" fractal dimension D1, and the large-scale "morphological" fractal dimension D2. The fractal dimensions are generated by subtracting the slope value from 1 ( $D=1$-slope) (Fig. 2, step 6). Detailed inspection of the dilation process revealed that the third very steep negative slope and the following positive slope are artifacts from overlapping boundaries. They were, therefore, not taken into account. The segment boundaries and the corresponding slopes in the Richardson plot were chosen by visual inspection. The selection of the endpoint of the first linear segment (slope) in the Richardson plot, from which D1 is extracted, is unproblematic because the break in slope is easy to recognize. The linear segment used for the calculation of D1 consists nearly always of the same points in scale (Log Diameter values: $0.477-1.123$ ). The selection of the endpoint of the linear segment from which the second slope D2 is obtained is much more problematic. Slight shifts may change the resulting slope considerably. This problem is further enhanced by the fact that the endpoint is located in the scale range where opposite segments of the dilated particle outline start to overlap. Although both slopes have been extracted, only D1 has been used for discrimination purposes.

To avoid the subjective selection of linear segments (slopes) for extracting fractal dimensions, the fractal spectrum method (Maria and Carey, 2002) has been used (Fig. 2, step 7). The spectrum corresponds to the first derivative of the Richardson curve. The resulting spectral values represent slope values for specific scales. Sets of four scale specific slope values ( $\log$ dilation diameter $=0.8,1.0,1.2$, and 1.4 ) were compared based on statistical multivariate analysis using the complete linkage method (furthest neighbor) (IBM SPSS Statistics). The criteria for selecting these specific scales (Log dilation diameters) will be explained in Section 5.3.3.

\subsection{Electron microprobe (EMP)}

Major element concentrations of glasses from three different layers of the Meerfelder Maar deposit (MFM03, MFM04, MFM05), one layer of the Pulvermaar deposit (PM30) and one layer of the Ulmener Maar deposit (UM35) in the WEVF, and two layers of the Eppelsberg Green Unit (EBGU03, EBGU05) in the EEVF were determined using a JEOL JXA-8200 SuperProbe (WD/ED combined microanalyzer) at the University of Bern (Switzerland). All electron microprobe (EMP) analyses shown here were done on groundmass glass. In total 137 spots were measured using a probe current of $20 \mathrm{nA}$, an acceleration voltage of $15 \mathrm{kV}$ and a spot size of $7 \mu \mathrm{m}$. International natural and synthetic glass standards were used for calibration.

\section{Results}

\subsection{Magma composition}

The West Eifel maar particles from Meerfelder Maar (MFM), Pulvermaar (PM) and Ulmener Maar (UM) have a strongly alkaline 
and highly silica-undersaturated (i.e. melilite-nephelinitic) composition (Mertes and Schmincke, 1985; Schmincke, 2007). The juvenile clasts from the East Eifel maar phase "Eppelsberg Green Unit" (EBGU) are slightly more evolved and less silica-undersaturated (i.e. basanitic) (Appendix D, Fig. 4A). All three West Eifel maar volcanoes are Na-rich $\left(\mathrm{Na}_{2} \mathrm{O} / \mathrm{K}_{2} \mathrm{O}>1.1\right)$, while the East Eifel maar phase Eppelsberg is K-rich $\left(\mathrm{Na}_{2} \mathrm{O} / \mathrm{K}_{2} \mathrm{O}<1.1\right)$ (Fig. 4B). Thus, the studied Eifel maar deposits build two compositionally distinct groups: (1) West Eifel Na-rich melilite-nephelinites and (2) East Eifel K-rich basanites.

\subsection{Qualitative description of juvenile lapilli to coarse ash}

Juvenile lapilli and coarse ash from the best-exposed West Eifel maar deposits (e.g. Pulvermaar, Meerfelder, Ulmener, Oberwinkler, Gemündener, Weinfelder maars) are characterized by subround to irregular morphologies, highly rugose textures, low to moderate vesicularities (5-40\%) and a tachylitic groundmass (Figs. 5A, B, C, Table 1). Vesicle shapes range from subround to irregular. Dense, angular, glassy (sideromelane) shards, typical for phreatomagmatic eruptions, are absent, while agglutinated particles resembling composite lapilli (sensu Fisher and Schmincke, 1984, and Bednarz and Schmincke, 1990) and cored lapilli typical of diatremes (i.e. autoliths, Lorenz, 1975; Dawson, 1980; Mitchell, 1986) are ubiquitous. Agglutinated juvenile particles consist of dark, dense, tachylitic droplets or patches within a lighter

\section{(A)}

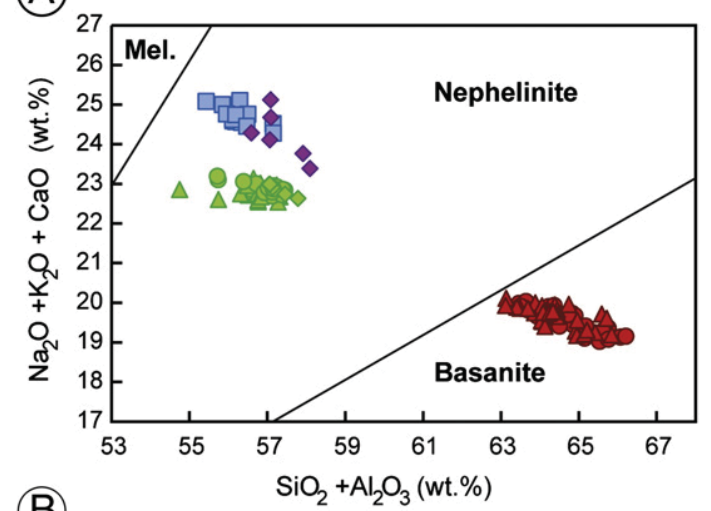

(B)

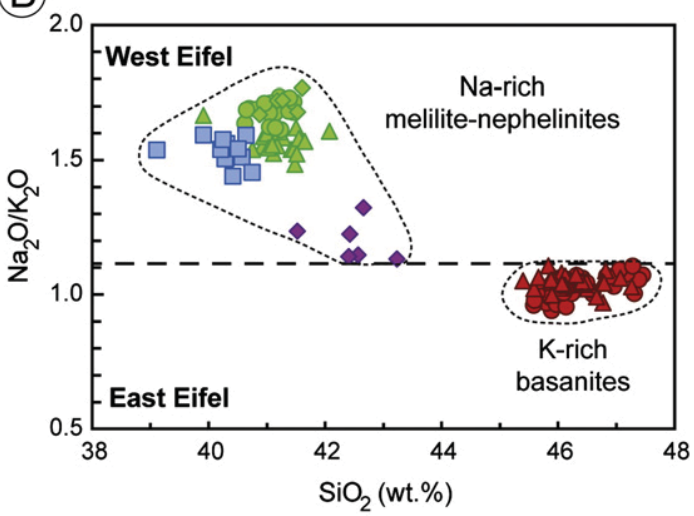

\begin{tabular}{|llll|}
\hline Meerfelder M. & Pulverm. & Ulmener M. & Eppelsberg G.U. \\
$\diamond$ MFM03 & $\square$ PM30 & $\diamond \mathrm{UM} 35$ & $\bullet$ EBGU03 \\
○ MFM05 & & & $\Delta$ EBGU05 \\
$\triangle$ MFM04 & & & \\
\hline
\end{tabular}

Fig. 4. EMP glass analyses for Eifel maar volcanoes. A) $\mathrm{SiO}_{2}+\mathrm{Al}_{2} \mathrm{O}_{3}$ vs. $\mathrm{Na}_{2} \mathrm{O}+\mathrm{K}_{2} \mathrm{O}+\mathrm{CaO}$ diagram showing the nephelinitic composition of the studied West Eifel maar volcanoes (Meerfelder Maar, Pulvermaar and Ulmener Maar) contrasting with the basanitic composition of the East Eifel maar phase Eppelsberg Green Unit; B) $\mathrm{SiO}_{2}$ vs. $\mathrm{Na}_{2} \mathrm{O} / \mathrm{K}_{2} \mathrm{O}$ diagram showing that the melilite nephelinites from the West Eifel are rich in $\mathrm{Na}\left(\mathrm{Na}_{2} \mathrm{O} / \mathrm{K}_{2} \mathrm{O}>\right.$ 1.1), while the basanitic Eppelsberg maar deposit is rich in $\mathrm{K}\left(\mathrm{Na}_{2} \mathrm{O} / \mathrm{K}_{2} \mathrm{O}<1.1\right)$. (grayish/brownish), higher vesiculated, tachylitic groundmass separated by a diffuse boundary (Fig. 5A, B). Cored lapilli consist of a crystal fragment (ol or cpx phenocryst/xenocryst) surrounded by a slightly vesiculated, tachylitic rind (Fig. 5C). The studied West Eifel particles contain mainly olivine and clinopyroxene phenocrysts \pm small nepheline and melilite crystals in the groundmass. They contain variable amounts of lithoclast and mafic to ultramafic xenolith fragments (up to 30 vol.\%). Thus, their density is highly variable.

In contrast, juvenile lapilli and coarse ash particles from the East Eifel maar phase (EBGU) are angular, poorly vesiculated (0-15\%) and glassy (sideromelane) shards characterized by smooth textures (Fig. 5D, Table 1). Juvenile clasts and lithoclasts erupted from EBGU are commonly coated by a brownish, sticky, fine-grained (clayey) rim (Fig. 5E, F). Fine-grained layers are rich in accretionary and armored lapilli (Fig. 5E).

Qualitative analysis of the juvenile particles based on light and scanning electron microscopy show clear differences in morphology, microtexture, vesicularity and internal organization between the West and East Eifel juvenile particles. Thus, it would certainly be advantageous if the qualitative discrimination could be completed by the quantification of some of these features (e.g. morphology and microtexture).

\subsection{Quantitative morphological and textural studies: fractal analysis}

\subsubsection{Testing the fractal technique in $3 D$ (SEM micro-CT)}

The SEM micro-CT reconstructions of juvenile particles enabled the fractal technique to be tested in 3D. Fractal analyses were performed on different cross-sections of the same particle (MFM45-4), in order to test the effect of cross section orientation and position on the fractal dimensions. The three perpendicular cross sections ( $\mathrm{X}, \mathrm{Y}$ and $\mathrm{Z}$ in Fig. 6A) intersecting approximately in the center of gravity of the particle show relatively small variations in both the textural dimension $(\mathrm{D} 1=1.11-1.07)$, and the morphological dimension $(\mathrm{D} 2=1.13-$ 1.08). In addition, the test performed on 14 parallel cross sections spaced by $\sim 15 \mu \mathrm{m}$ (Fig. $6 \mathrm{~B}$, Appendix B) shows that D2 varies significantly (1.21-1.05) with the position of the cross section within the particle, whereas D1 shows a smaller variation within the same cross sections (1.13-1.04). Most of the "outlier" fractal values, however, correspond to cross sections with small surface area, i.e. for which the cutting plane is located at a distance equal to $80 \%$ or more of the distance between the center and the edge of the particle. Those sections are thus not appropriate for fractal analysis and should be avoided. Doing so the spread of both the D1 and D2 values is much smaller (D1 = 1.09-1.04, D2 = 1.10-1.05). Consequently, only particle cross sections with a diameter $>150 \mu \mathrm{m}$ were used for subsequent fractal analyses in thin sections.

\subsubsection{Richardson plots (dilation method)}

Fractal dimensions D1 and D2 from particles from the six layers of the Meerfelder Maar deposit, and from the two layers of the Pulvermaar, Ulmener Maar and Eppelsberg Green Unit deposits, were extracted from the corresponding Richardson plots. Ten particles per layer were analyzed resulting in a total of 120 analyzed particles. Our results are compared with the fractal dimensions of particles erupted from Katla volcano (Iceland), which have been formed by magmatic processes without contribution of external water, and with fractal dimensions of particles erupted from Grimsvötn volcano, which have been formed by fragmentation processes, in which external water played a crucial role (Maria and Carey, 2002).

A larger number of layers of the Meerfelder Maar (MFM) deposit were analyzed in order to examine the variability of the fractal dimensions between layers presumably formed through similar types of processes. Even though the 60 MFM particles show a relatively large variation in both fractal dimensions (D1 and D2), they clearly cluster outside the field defined by the phreatomagmatic particles of Grimsvötn, and they match the field defined by the magmatic particles of Katla (Fig. 7A). Based on the consistency of the Meerfelder Maar 

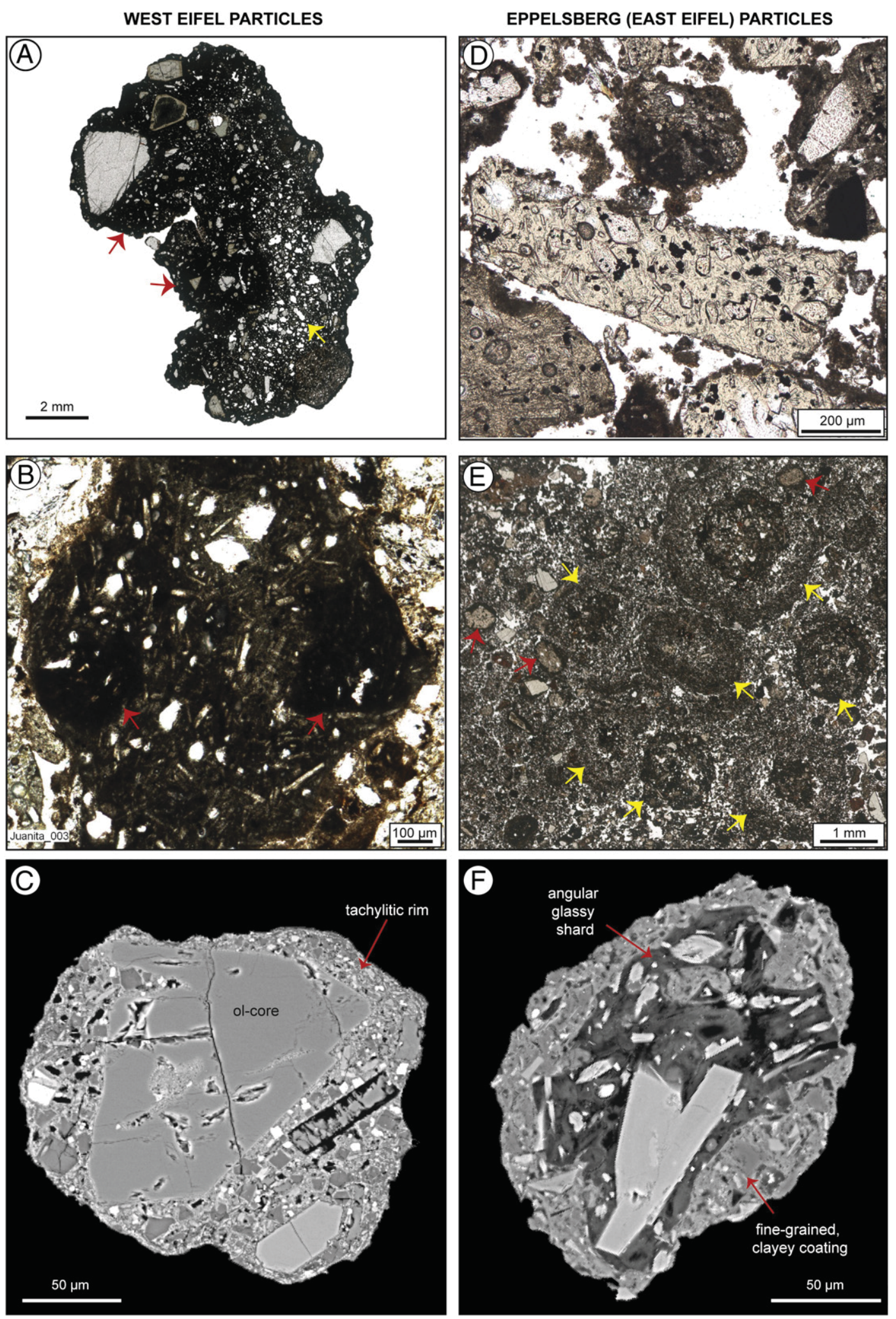

Fig. 5. Compilation of photomicrographs showing the characteristic features of juvenile particles from the studied West Eifel maars (A-C) and from the "Green Unit", a maar phase of Eppelsberg volcano, East Eifel (D-F). A) Typical subround to irregular shaped, tachylitic West Eifel juvenile particle, consisting of several agglutinated particles (i.e. composite lapillus). Dark, low vesicular (0-10\%) droplets or patches (red arrows) are agglutinated with a lighter, highly vesiculated (up to 50\%) groundmass (yellow arrow). B) Another example of a composite lapillus. Red arrows show darker, low vesicular droplets within the lighter and slightly more vesiculated round particle. C) Common cored lapillus consisting of a crystal core (olivine) surrounded by a tachylitic rim. D) Typical angular, low to non-vesicular ( $0-10 \%$, sideromelane shard from Eppelsberg (East Eifel). E) Accretionary/armored lapilli (yellow arrows) abundant in the Eppelsberg Green Unit deposit. Note sideromelane shards coated by a fine-grained rim (red arrows). F) Close-up of an angular, non-vesicular, sideromelane shard coated by a sticky, fine-grained (clayey) rim. 

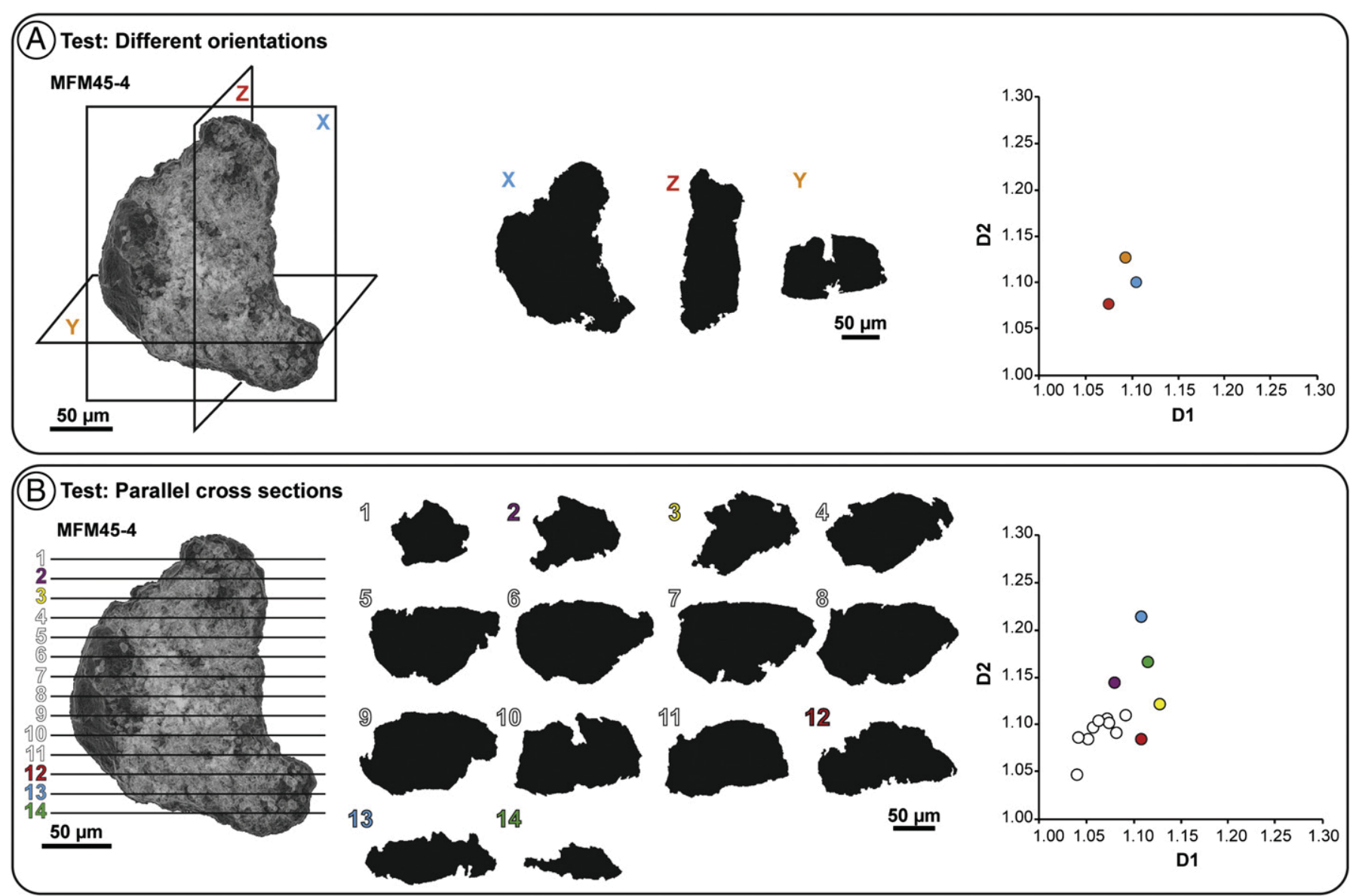

Fig. 6. Consistency tests of the fractal technique using several cross sections obtained from the 3D SEM micro-CT reconstruction of the particle MFM45-4 (see Vonlanthen et al., 2014). A) Influence of the cross section orientation on the calculated fractal dimensions; B) Influence of the location of parallel cross sections on the calculated fractal dimensions.

fractal values with the one of the fields defined by the Icelandic particles, we decided to extend our study to other maar volcanoes in the Eifel Volcanic Field but limit the number of layers per volcano to two.

The particles from the other WEVF deposits i.e. from Pulvermaar and Ulmener Maar have similar spreads for both fractal dimension as the Meerfelder Maar particles (D1 = 1.025-1.103; D2 = 1.035-1.135). The juvenile particles from the East Eifel maar deposit (Eppelsberg Green Unit) are characterized by similar morphological dimensions $(\mathrm{D} 2=1.018-1.096)$, but definitely smaller textural $(\mathrm{D} 1=1.004-$ 1.027) fractal dimensions (Fig. 7B, Appendix C). The textural fractal dimensions of the particles from the Eppelsberg Green Unit maar phase coincide with the textural dimensions of the phreatomagmatic particles from Grimsvötn (Maria and Carey, 2002). The morphological fractal dimensions of the Eifel particles show a smaller spread than the values given for Katla and Grimsvötn particles. Recalculations of fractal values for Icelandic particles have shown, however, that many of the morphological fractal dimensions seem to be overestimated. The cause is the choice of the second linear segment in the Richardson plots. It seems that Maria and Carey (2002) selected in many cases the third very steep slope as D2. Careful follow-up of the dilation process revealed that the final steepening in the part of the Richardson plot with negative slope is a consequence of first overlaps of opposite segments of the contours (see Richardson plot in Fig. 2 and 3).

However, regardless of which D2 (slope 2) is chosen, it has no consequence on the interpretation of the Richardson plots because the values for the particles formed by either of the two processes largely overlap and the morphological fractal dimension does not to allow discriminating between both formation processes. The comparison of the textural dimensions (D1 values), however, gives a clear cut separation between East and West Eifel maar particles with a limiting value of approximately 1.025-1.027. It is remarkable that a similar limiting value ( $\mathrm{D} 1=\sim 1.029$ ) was found between Katla and Grimsvötn particles.

The weakness of the analysis of the Richardson plot is the visual choice of the section from which the slope is determined. The same data were, therefore, also analyzed using the fractal spectrum technique (Maria and Carey, 2002).

\subsubsection{Fractal spectrum technique and multivariate statistical analysis}

The fractal spectrum technique is most appropriate for the comparison of multifractal contours provided that the selected set of spectral values are chosen at the same scales for all particles (Appendix C). Instead of taking the slopes of linear segments in the Richardson plots, slopes (= spectral value) at given scale values (first derivatives of the Richardson curve) are compared. Sets of 4 spectral values at given scales were chosen for each particle. Because only small-scale (textural) fractal dimensions are useful to discriminate particles formed by different processes (as shown by the fractal dimensions obtained from the Richardson plots), the set was restricted to scales within D1 in the Richardson plot. To facilitate comparison with the data from Katla and Grimsvötn particles, the same small-scale values as Maria and Carey (2002) were chosen (at Log dilation diameter $=0.8,1.0,1.2$, and 1.4 pixels, Fig. 2 ).

Cluster analyses of the spectral value sets based on the complete linkage method (furthest neighbor) were performed and the results were visualized in a hierarchical tree (dendrogram). The squared Euclidean distance is used as a measure of dissimilarity between the particles (Fig. 8). In the dendrogram, the Grimsvötn phreatomagmatic particles and the Katla magmatic particles cluster in two different groups separated by the second largest squared Euclidean distance. 

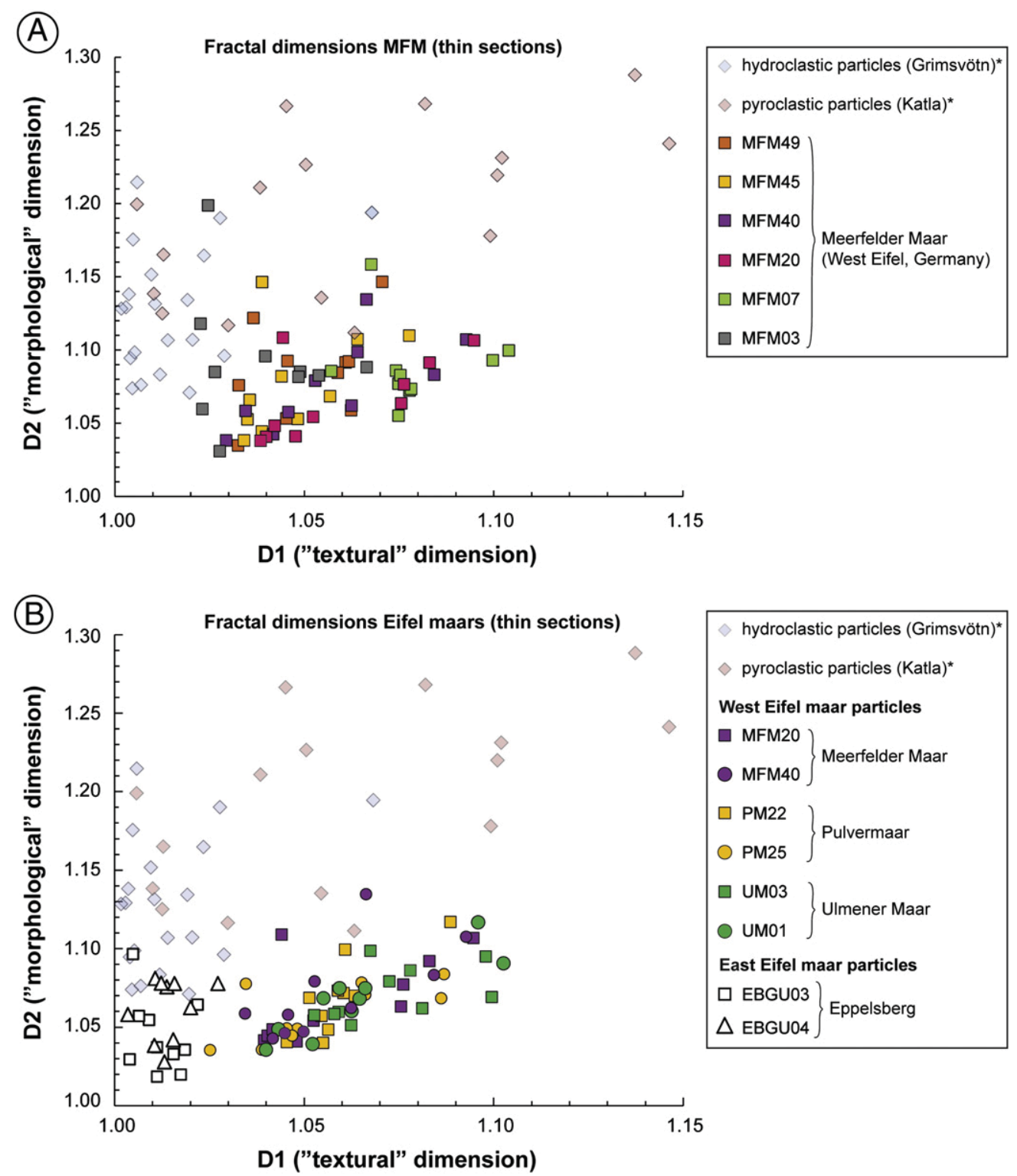

Fig. 7. D1 (textural dimension) vs. D2 (morphological dimension) diagram showing the results of the fractal analyses performed on the thin sections for A) Meerfelder Maar, B) Meerfelder Maar, Pulvermaar, Ulmener Maar and Eppelsberg Green Unit. The fractal values of two Icelandic volcanoes (Katla and Grimsvötn) obtained by Maria and Carey (2002) are shown for comparison.

The West Eifel maar particles (yellow labels) are clustered with the Katla magmatic particles (red labels), while the particles from the East Eifel maar phase (Eppelsberg Green Unit, EBGU) (bright blue labels) are grouped with the phreatomagmatic particles from Grimsvötn (dark blue labels). Among a total of 120 particles only six "mismatches" occur, one East Eifel particle is located within the Katla-West Eifel group, and three West Eifel and two Katla particles are located within the Grimsvötn-East Eifel group.

Two particles from Katla (119-120) cluster in a separate group characterized by the largest dissimilarity (i.e. squared Euclidean distance) compared to the rest of the particles. The cause for this classification is the very irregular particle shapes, which are due to the higher content of vesicles. Even though the Katla-West Eifel group was statistically further classified in subgroups, we opted not to use further subdivisions for our interpretations due to the relatively small dissimilarity between those groups.

The cluster analysis thus strengthens the result obtained from the Richardson plots and confirms the successful discrimination between WEVF and EEVF maar particles.

\section{Discussion}

6.1. What do classical microscopy and fractal analysis tell us about the Eifel maar eruptions?

The main cause of acceleration and fragmentation of magmas are stresses exerted on the magma by rapidly expanding gases, either exsolved from the magma or formed through the volatilization of external fluids. Acceleration of magma-gas-bubble mixtures results in high strain rates which lead to fragmentation due to fluid instabilities or brittle fracture. Unloading elastic wave propagation downward into the magma, layer-by-layer vesicle bursting and rapid gas-filtration flow are fragmentation mechanisms occurring after sudden decompression of magma (Alibidirov and Dingwell, 1996). The metallurgical fuel coolant interaction ( $\mathrm{FCI}$ ) model has been used as analog for explaining fragmentation occurring during magma-external water interactions. Destabilization of vapor films and thermal stresses are responsible for FCI fragmentation (Morrissey et al., 2000). All fragmentation processes can occur in parallel. The large variety in fragment shape and surface 


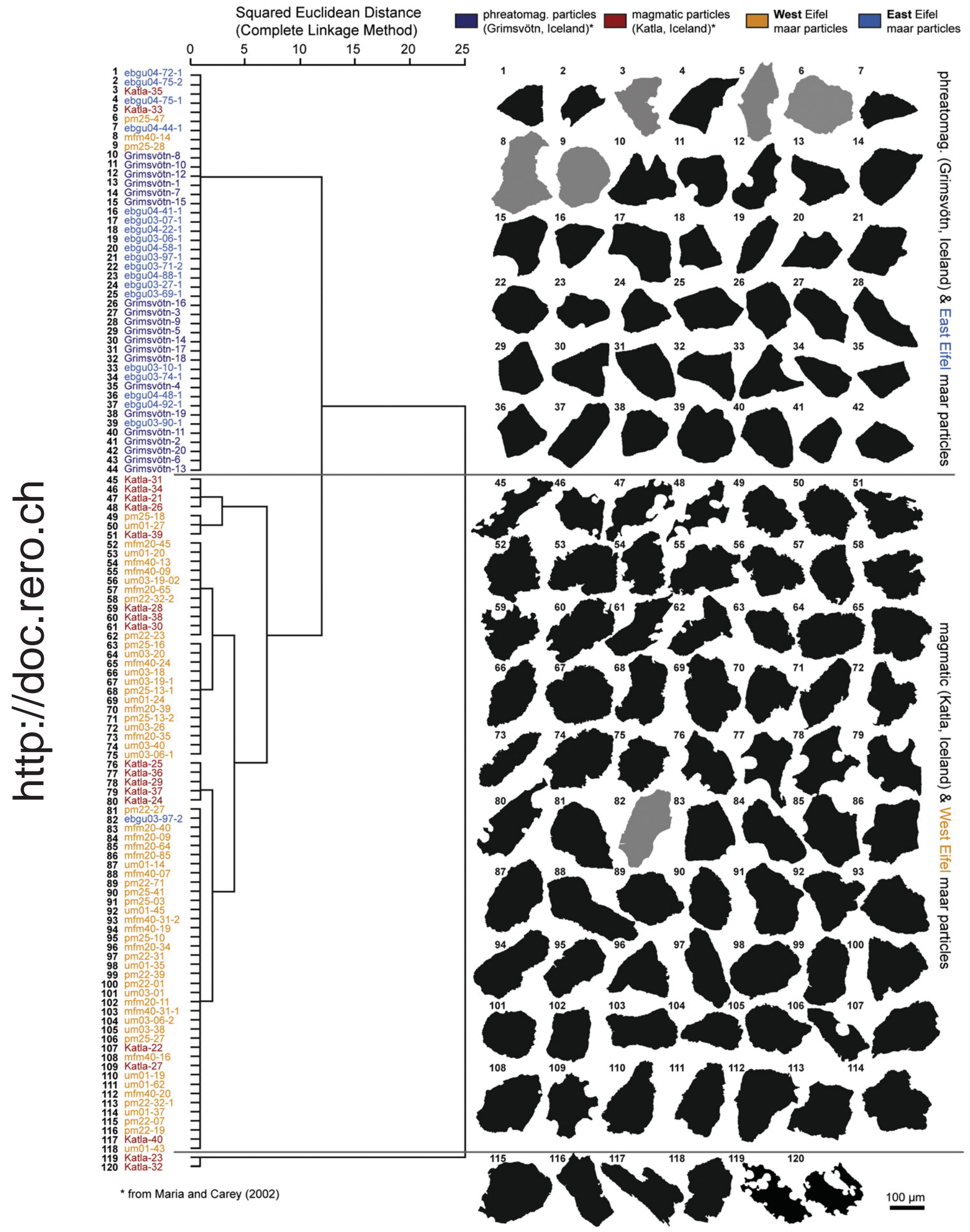


morphology is thus not surprising, when considering the number of fragmentation mechanisms and the range of properties the magma can have before fragmentation.

Despite the large number of parameters playing a role in juvenile particle fragmentation, the prevailing view is that the amount and size of vesicles present in the magma before fragmentation have the major control on juvenile particle morphology. Fracture surfaces will preferentially follow the shortest path between two neighboring vesicles. The fracture surface will, therefore, be a composite of intra and inter vesicle surfaces. The more numerous and/or larger the vesicles are prior to magma fragmentation, the higher the likelihood that the particle surface morphology is composed of the inner walls of broken vesicles. Particles resulting from the fragmentation of magmas with large vesicles will be complex at large scale, but rather smooth at small scales. Fracture surfaces of magmas with numerous small vesicles will be complex at small scale and simpler at large scales. Particles from magmas with a large distribution of vesicle sizes at the start of fragmentation will have complex surfaces at all scales. The latter situation is typical for "magmatic" particles i.e. which are the result of fragmentation induced by exsolving and expanding gases originally dissolved in the magma.

The only way magmas with small number of vesicles may fracture is by external addition of water. The fracture surfaces of such particles will be dominated by the intra vesicle surfaces i.e. by the fracture mechanism. Several fracturing processes are effective during magma-coolant interaction. Fracturing due to fluid instabilities and the collapse of vapor films result in fine ash particles $(<63 \mu \mathrm{m})$ with highly irregular, "mosslike" surfaces. Quenching of the melt due to high heat transfer across the aforementioned irregular surfaces induces thermal stress waves. Fragmentation due to thermal shock produces blocky particles with straight surfaces (i.e. smooth surfaces at small scales) (e.g. Heiken, 1974; Schmincke, 1977; Wohletz, 1983; Fisher and Schmincke, 1984; Heiken and Wohletz, 1985; Zimanowski et al., 1991; Dellino and La Volpe, 1996; Büttner et al., 2002), which are larger (mainly 250-63 $\mu \mathrm{m}$ ) than the particles formed by vapor film collapse (Wohletz, 1983).

Similar to what we found in our study, small scale features such as surface roughness of particles formed during the 1982-1983 Galunggung eruption (Indonesia) were smaller during "wet" phases (Ersoy et al., 2007). The particles emitted during the "phreatomagmatic" eruption of Grimsvötn had very low small scale fractal dimensions, as well. The fine ash fraction ( 3 to 5 phi) from a rhyolitic tuff ring volcano, Tepexitl Mexico, and particles produced by FCl experiments with the same material were characterized by blocky particles and smooth surfaces (AustinErickson et al., 2008). Even when the addition of external fluids occurred after major exsolution of magmatic gases and vesicle formation, typical for Askja volcano (Iceland), the juvenile fine ash fraction shows primarily the blocky morphology and the smooth topography at small scale (Graettinger et al., 2013).

The Eifel Volcanic Field is regarded as the type locality for maar eruptions, which are traditionally thought to be triggered by the addition of external water.

It is, therefore, not surprising, that the fractal analyses of juvenile particles from the maar phase in the East Eifel (Eppelsberg Green Unit) match the morphological observations made in the previous studies of particles resulting from magma-external fluid interactions. The very small textural fractal dimensions $(\mathrm{D} 1=1-1.023)$ and the relatively small morphological dimensions (D2 $<1.1$ ) are in agreement with fractal values observed for classical phreatomagmatic particles (e.g. Grimsvötn, Iceland, Maria and Carey, 2002). In addition, the common accretionary lapilli and fine-grained (clayey) coating stuck around the particles clearly indicate the presence of water/steam in the transport/ depositional system. Thus, deposit and particle characteristics clearly suggest that the Eppelsberg Green Unit was the result of a primarily phreatomagmatic eruption.

The picture is, however, very different for the juvenile particles from the maar volcanoes located in the West Eifel Volcanic Field. The quantitative shape analyses performed in this study of WEVF particles reinforce previous qualitative microscopic observations (Schmincke, 2007; Rausch, 2014), confirming that juvenile particles from classical West Eifel maars (e.g. Meerfelder Maar, Ulmener Maar and Pulvermaar) lack the diagnostic features of phreatomagmatic particles in the size range 63-250 $\mu \mathrm{m}$. Though West Eifel maar particles (fractions $>125 \mu \mathrm{m}$ ) share characteristics with the "moss-like" clasts described by Wohletz (1983) and the "round to subround, rugged particles" mentioned by Zimanowski et al. (1991) as typical for FCI particles resulting from water film collapse, the lack of blocky clasts with smooth surfaces, described to be dominant in the medium to coarse grained ash fractions $(>63 \mu \mathrm{m})$ of natural and experimentally produced phreatomagmatic particles, suggest that the fragmentation processes during West Eifel maar eruptions were different than for classical phreatomagmatic eruptions (e.g. Taal Volcano, Philippines; Ubehebe, California, etc.). Their large textural fractal dimensions (D1 > 1.023), coincide with fractal dimensions typical for magmatic particles (e.g. Katla, Iceland, Maria and Carey, 2002). The fractal analyses and the qualitative observations, thus suggest that the formation of WEVF maar particles was dominated by magmatic fragmentation processes.

Moreover, the West Eifel maar highly rugose particles consist nearly always of dark tachylitic glass, suggesting lower cooling rates, whereas the round to subround, rugged particles produced during watermagma interaction experiments (Zimanowski et al., 1991) using a melt with a similar composition than the West Eifel magmas (i.e. olivine-melilititic) consist of "light or even non-colored glass" suggesting very rapid cooling.

\subsection{Influence of transport mechanisms}

The difference in particle morphology could also be caused by different transport modes and distances (e.g. Maria and Carey, 2007). The studied West Eifel maar deposits include layers interpreted to have been transported and deposited as fallout, surge and debris jets (Appen$\operatorname{dix} A$ ). Surge and debris jet transport is accompanied by particle collisions, which tend to smoothen the surface of the particles. The East Eifel Eppelsberg Green Unit is thought to have been transported and deposited as alternating wet and dry fallouts as evidenced by the good sorting, constant thickness and normal grading of single layers and variable content of accretionary and armored lapilli. Assuming all studied deposits to be the result of phreatomagmatic eruptions with similar starting particle shapes (in the range of the studied particles), one should expect a smoothening of the particles transported through surge and debris jets relative to fallout particles. Thus, the shape of the West Eifel particles transported by surge and debris jets should have been more affected by collisional smoothing than the Eppelsberg particles. The West Eifel particles, however, are characterized by the largest small-scale irregularities. Thus, we exclude transport and deposition mechanisms to be the main reason for the differences in particle shape between the studied West and East Eifel particles.

\subsection{Recycling of juvenile particles}

Juvenile particle recycling is a common process in scoria cone and maar eruptions. Particles ejected by relatively low energetic explosions can either fall directly back into the vent, or they can be temporarily deposited on the inner crater walls and subsequently fall back into the 
vent during collapse of the steep, unstable inner crater walls. These particles are re-ejected during the next explosions of the same eruption (Houghton and Smith, 1993). In this way, the shape of the particles can be modified by repeated reworking, partial melting and coating of the particle by new magma. Such processes may transform primary phreatomagmatic particles to secondary "pseudo" magmatic particles. The extreme scenario would be that all particles in the West Eifel maar deposits would have been affected by recycling. Light microscopy and BSE images, however, do not show evidence of recycled particles (e.g. dense, angular, glassy shard embedded within a tachylitic, higher vesiculated groundmass). Even though recycling of a fraction of the juvenile particles erupted in Eifel maars cannot be ruled out and is most likely an important process, the striking consistency in the differences (e.g. morphology, microtexture, type of glass, vesicularity and internal organization) between the studied West and East Eifel maar particles, is not in favor of a dominant recycling process.

\subsection{What are the differences between the East and West Eifel Volcanic Field?}

Phreatomagmatic eruptions require the presence of a shallow or surface water source. The bed rock lithology in the East Eifel Volcanic Field (EEVF) has the requisites for the occurrence of a confined aquifer (= highly permeable, unconsolidated sand and gravel deposits) underlain by impermeable, consolidated Devonian rocks and sealed by an aquitard (=low permeable clay layer) (Fig. 9A), representing a mixed hard-soft environmental setting (Lorenz, 2003; Ross et al., 2011). The highly fractured crust below the EEVF facilitates the rapid ascent of magma to the shallow groundwater level. Thus, the EEVF has a classical geological and hydrological setting for effective and explosive interaction of rising magma with groundwater.

On the other hand, the geological setting in the WEVF does not favor the development of an extensive aquifer, neither confined nor unconfined. The bedrock underlying the WEVF consists mainly of impermeable Lower Devonian rocks (Fig. 9B) (i.e. hard-rock setting, Lorenz, 2003). The only permeable sediments, thus the only potential level for a primary aquifer in the West Eifel, are the Lower Triassic Buntsandstein deposits (R. Poppe, 2013, personal communication). These sediments are only preserved in local depressions in the southwestern and northwestern part of the field, but are absent below the studied maar volcanoes (i.e. Meerfelder Maar, Pulvermaar, Oberwinkler Maar, Ulmener Maar). This is evidenced by the lack of corresponding lithoclasts within the maar deposits (Appendix A). A fractured bedrock aquifer is also unlikely because there is no evidence for large hydraulic conductivity between the fractures cutting the crust underlying the WEVF. This is shown in the striking different elevations of the water table (up to $80 \mathrm{~m}$, Fig. 10) of the neighboring Dauner maars (i.e. Gemündener, Weinfelder and Schalkenmehrener maars).

The remaining alternative external water source for hypothetical phreatomagmatic eruptions in the West Eifel is surface water (e.g. streams, rain or snow). Lorenz (1973) proposed the interaction of magma with stream water to be responsible for the West Eifel maar volcanism. We think, however, that streams represent a very limited water supply, making a dominant phreatomagmatic model for the formation of West Eifel maar volcanoes questionable.

A further difference between the WEVF and EEVF is the magma composition. West Eifel magmas are mainly foiditic (red triangles/circles in Fig. 1), while a significant portion of East Eifel magmas are basanitic (blue triangles/circles in Fig. 1). The melilite-nephelinitic magmas of the studied West Eifel maar volcanoes are inferred to be $\mathrm{CO}_{2}$-rich based on experimental studies on the genesis of such silica-undersaturated magmas (Brey, 1976; Brey and Green, 1976), the strong $\mathrm{CO}_{2}$-degassing in the EVF (e.g. Giggenbach et al., 1991; Aeschbach-Hertig et al., 1996), as at Ulmener Maar and the close association of these magmas with carbonatites.

Furthermore, it has been shown that $\mathrm{CO}_{2}$ solubility increases with increasing pressure and decreasing silica-content (Mysen et al., 1975; Wyllie, 1979). Brooker et al. (2001) have demonstrated that up to 15$18 \mathrm{wt} . \% \mathrm{CO}_{2}$ can be dissolved in melilititic melts at mantle conditions. Thus, we suggest that fast magma rise may have led to strong exsolution of large amounts of $\mathrm{CO}_{2}$ and the sudden increase in pressure within the vesicles may have triggered magmatic fragmentation prior to the shallow interaction with variable amounts of ground or surface water. Magmatic fragmentation at depth is supported by the occurrence of mantle to lower crust xenoliths coated by agglutinated particles in

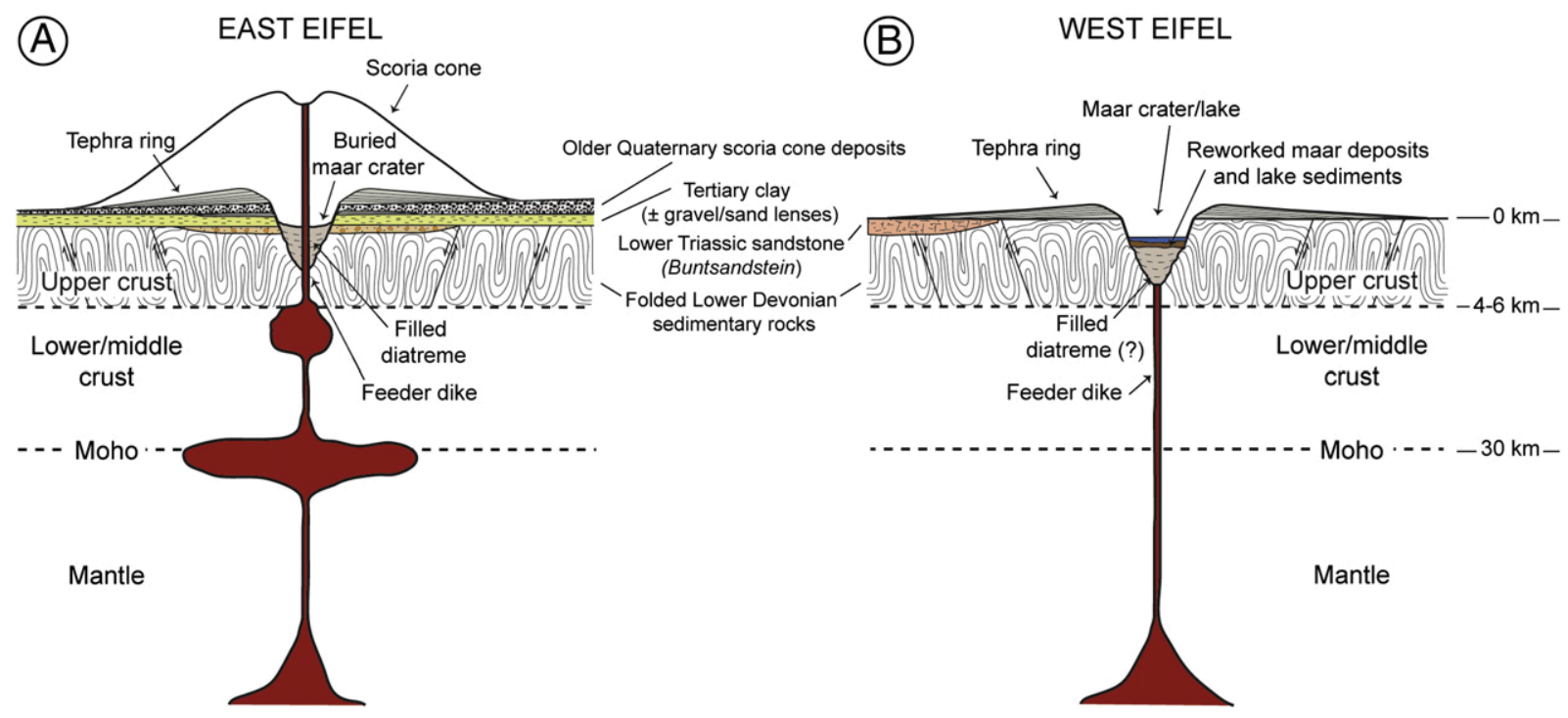

Fig. 9. A) Schematic cross section of the East Eifel, showing the configuration of the basement. Highly fractured and folded, impermeable Devonian rocks are overlain by a low permeable Tertiary clay layer locally containing sandstone and gravel lenses. Based on the lack of mantle or lower/middle crustal xenoliths within the tephra deposits (Schmincke, 2007), the magma reservoir is interpreted to be at the base of the upper crust. B) Schematic cross section of the West Eifel (example Meerfelder Maar). The upper crust consists of strongly folded, fractured Lower Devonian rocks overlain in local morphological depressions by Buntsandstein sediments. The depth of the magma reservoir beneath Meerfelder Maar is estimated based on peridotite (upper mantle) xenoliths found within the deposit. In the case of Pulvermaar and Ulmener Maar the magma reservoir is interpreted to be slightly shallower (lower/middle crust) based on the granitic lower/middle crust xenoliths found within the ejected tephra. 

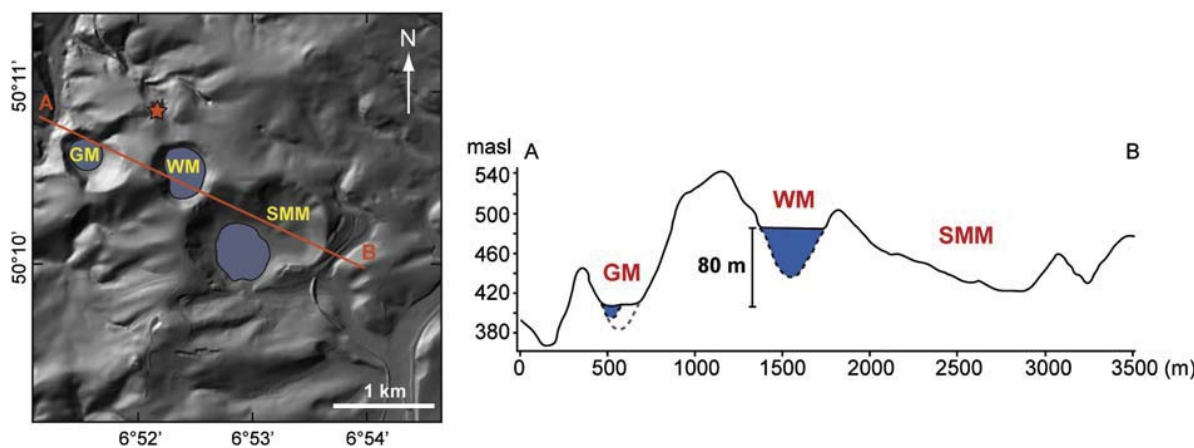

Fig. 10. Digital Elevation Model (DEM) of the Dauner maars obtained from @GeoBasis-DE/LVermGeoRP2011-05-17. GM: Gemündener Maar, WM: Weinfelder Maar and SMM: Schalkenmehrener Maars. Profile A-B across the GM, WM and SMM craters shows the striking difference in water table elevation (up to $80 \mathrm{~m}$ ). The location of the tephra pit where deposits of Gemündener Maar (GM) and Weinfelder Maar (WM) are cropping out is indicated by an orange star.

many WEVF volcanoes (Schmincke, 2007; Rausch, 2014). The slightly less silica-undersaturated basanitic magmas, as the EEVF Eppelsberg magma have most likely a lower $\mathrm{CO}_{2}$ solubility, which may be the reason for a slower ascent and stagnation in shallower levels. This combined with the presence of a confined aquifer in the East Eifel are clear evidence that the triggering of the eruption of the Eppelsberg Green Unit was the contact of magma with groundwater at shallow depths.

The fact that East Eifel melilite-nephelinite volcanoes Herchenberg and Leilenkopf (Bednarz and Schmincke, 1990) share practically the same geological setting with Eppelsberg, but also lack conventional criteria for phreatomagmatic fragmentation processes, indicates that the magma composition, and hence the $\mathrm{CO}_{2}$ content, can have a large influence or probably even dictate the prevailing mode of fragmentation and style of eruption.

\section{Concluding remarks}

In this work, fractal analysis and the fractal spectrum method have been applied for the first time to analyze particle shapes from maar deposits in order to determine likely fragmentation processes and eruption styles. As benchmark the discrimination criteria obtained from particles sampled from two historic eruptions in Iceland, for which fragmentation processes were known, have been used. The fractal analysis confirmed microscopic observations, in that the studied WEVF maar eruptions were not dominated by phreatomagmatic processes and were largely influenced by magmatic fragmentation at depth, whereas EEVF maar phases fulfill all the characteristics of classical maar deposits, interpreted to be phreatomagmatic in origin. The eruption mechanisms derived from microscopic observations and the quantitative particle shape analyses are compatible with both the geological setting of the studied volcanoes and the chemical composition of the eruption products.

Supplementary data to this article can be found online at http://dx. doi.org/10.1016/j.jvolgeores.2014.11.008.

\section{Acknowledgments}

The present study was financially supported by the Swiss National Science Foundation (Marie-Heim Vögtlin Program) and the University of Fribourg (Switzerland). The authors thank S. Dettmar for the preparation of excellent polished thin sections of particle mounts. Special thanks go to C. Neururer (University of Fribourg) for technical support during SEM-based automated particle imaging and analysis. We are also grateful to M. Robyr (University of Bern) for assistance during EMP measurements. We thank Ulrich Kueppers and an anonymous reviewer for their valuable comments that helped to improve the manuscript.

\section{References}

Aeschbach-Hertig, W., Kipfer, R., Hofer, M., Wieler, R., Signer, P., 1996. Quantification of gas fluxes from the subcontinental mantle: the example of Laacher See, a maar lake in Germany. Geochim. Cosmochim. Acta 60 (1), 31-41.

Alibidirov, M., Dingwell, D.B., 1996. Magma fragmentation by rapid decompression. Nature 380, 146-148.

Austin-Erickson, A., Buttner, R., Dellino, P., Ort, M.H., Zimanowski, B., 2008. Phreatomagmatic explosions of rhyolitic magma: experimental and field evidence. J. Geophys. Res. Solid Earth 113 (B11). http://dx.doi.org/10.1029/2008JB005731.

Baumann, G., Barth, A., Nonnenmacher, T.F., 1994. Measuring fractal dimensions of cell contours: practical approaches and their limitations. Fractals in Biology and Medicine. Birkhäuser, Basel, pp. 182-189.

Bednarz, U., Schmincke, H.U., 1990. Evolution of the Quaternary melitite-nephelinite Herchenberg volcano (East Eifel). Bull. Volcanol. 52 (6), 426-444.

Brey, G., 1976. $\mathrm{CO}_{2}$ solubility and solubility mechanisms in silicate melts at high pressures. Contrib. Mineral. Petrol. 57 (2), 215-221.

Brey, G.P., Green, D.H., 1976. Solubility of $\mathrm{CO}_{2}$ in olivine melilitite at high pressures and role of $\mathrm{CO}_{2}$ in the earth's upper mantle. Contrib. Mineral. Petrol. 55 (2), 217-230.

Brooker, R.A., Kohn, S.C., Holloway, J.R., McMillan, P.F., 2001. Structural controls on the solubility of $\mathrm{CO}_{2}$ in silicate melts: part I: bulk solubility data. Chem. Geol. 174 (1), 225-239.

Büchel, G., 1994. Vulkanologische Karte der West- und Hocheifel 1:50,000, Koblenz. (Hrsg.) Landesvermessungsamt, Rheinland-Pfalz.

Büchel, G., Lorenz, V., 1982. Zum Alter des Maarvulkanismus der Westeifel. Neues Jahrb. Geol. Palaontol. Abh. 163, 1-22.

Büchel, G., 1993. Maars of the Westeifel (Germany). In: Negendank, J.F.W., Zolitschka, B. (Eds.), Palaeolimnology of European Maar Lakes. Lecture Notes in Earth Sciences 49. Springer, Berlin-Heidelberg, pp. 1-13.

Büchel, G., Mertes, H., 1982. Die Eruptionszentren des Westeifeler Vulkanfeldes. Z. Dtsch. Geol. Ges. 133, 409-429.

Büttner, R., Dellino, P., Zimanowski, B., 1999. Identifying magma-water interaction from the surface features of ash particles. Nature 401 (6754), 688-690.

Büttner, R., Dellino, P., La Volpe, L., Lorenz, V., Zimanowski, B., 2002. Thermohydraulic explosions in phreatomagmatic eruptions as evidenced by the comparison between pyroclasts and products from Molten Fuel Coolant Interaction experiments. J. Geophys. Res. Solid Earth 107 (B11), 1978-2012 (ECV-5).

Carey, S., Maria, A., Sigurdsson, H., 2000. Use of fractal analysis for discrimination of particles from primary and reworked jökulhlaup deposits in SE Iceland. J. Volcanol. Geotherm. Res. 104 (1), 65-80.

Cioni, R., D'Oriano, C., Bertagnini, A., 2008. Fingerprinting ash deposits of small scale eruptions by their physical and textural features. J. Volcanol. Geotherm. Res. 177 (1), 277-287.

Crowe, B.M., Fisher, R.V., 1973. Sedimentary structures in base-surge deposits with special reference to cross-bedding, Ubehebe Craters, Death Valley, California. Geol. Soc. Am. Bull. 84 (2), 663-682.

Dawson, J.B., 1980. Kimberlites and Their Xenoliths. Springer, Berlin Heidelberg, pp. 1-252.

Dellino, P., La Volpe, L., 1995. Fragmentation versus transportation mechanisms in the pyroclastic sequence of Monte Pilato-Rocche Rosse (Lipari, Italy). J. Volcanol. Geotherm. Res. 64 (3), 211-231.

Dellino, P., La Volpe, L., 1996. Image processing analysis in reconstructing fragmentation and transportation mechanisms of pyroclastic deposits. The case of Monte PilatoRocche Rosse eruptions, Lipari (Aeolian islands, Italy). J. Volcanol. Geotherm. Res. 71 (1), 13-29.

Dodds, P.S., Rothman, D.H., 2000. Scaling, universality, and geomorphology. Annu. Rev. Earth Planet. Sci. 28, 571-610.

Eiríksson, J., Sigurgeirsson, M., Hoelstad, T., 1994. Image analysis and morphometry of hydromagmatic and magmatic tephra grains, Reykjanes volcanic system, Iceland. Jökull 44, 41-65.

Ersoy, O., Gourgaud, A., Aydar, E., Chinga, G., Thouret, J.-C., 2007. Quantitative scanningelectron microscope analysis of volcanic ash surfaces: application to the 1982-1983 Galunggung eruption (Indonesia). Geol. Soc. Am. Bull. 119, 743-752. 
Fisher, R.V., Schmincke, H.U., 1984. Pyroclastic Rocks. Springer, Berlin, p. 472

Fisher, R.V., Waters, A.C. 1970. Base surge bed forms in maar volcanoes. Am. J. Sci. 268 (2) 157-180.

Fuchs, K., von Gehlen, K., Mälzer, H., 1983. Plateau Uplift: The Rhenish Shield, A Case History (411 pp., Berlin).

Giggenbach, W.F, Sano, Y Schmincke, HU, 1991. CO -rich gases from Lakes Nyos and Monoun, Cameroon; Laacher See, Germany; Dieng, Indonesia, and Mt. Gambier, Australia-variations on a common theme. J. Volcanol. Geotherm. Res. 45 (3), 311-323.

Graettinger, A.H., Skilling, I., McGarvie, D., Hoskuldsson, A., 2013. Subaqueous basaltic magmatic explosions trigger phreatomagmatism: a case study from Askja, Iceland. J. Volcanol. Geotherm. Res. 264, 17-35.

Heiken, G., 1972. Morphology and petrography of volcanic ashes. Geol. Soc. Am. Bull. 83 (7), 1961-1988.

Heiken, G., 1974. An atlas of volcanic ash. UMI 101

Heiken, G., Wohletz, K., 1985. Volcanic Ash. University Presses of California, Chicago, Harvard \& MIT

Honnorez, J., Kirst, P., 1975. Submarine basaltic volcanism: morphometric parameters for discriminating hyaloclastites from hyalotuffs. Bull. Volcanol. 39, 441-465.

Houghton, B.F., Smith, R.T., 1993. Recycling of magmatic clasts during explosive eruptions: estimating the true juvenile content of phreatomagmatic volcanic deposits. Bull. Volcanol. 55 (6), 414-420

Kaye, B.H., 1978. Specification of the ruggedness and/or texture of a fine particle profile by its fractal dimension. Powder Technol. 21 (1), 1-16.

Kilps, J.R., Logan, B.E., Alldredge, A.L., 1994. Fractal dimensions of marine snow determined from image analysis of in situ photographs. Deep-Sea Res. I Oceanogr. Res. Pap. 41 (8), 1159-1169.

Kindratenko, V.V., Van Espen, P.J., Treiger, B.A., Van Grieken, R.E., 1994. Fractal dimensional classification of aerosol particles by computer-controlled scanning electron microscopy. Environ. Sci. Technol. 28 (12), 2197-2202.

Kueppers, U., Perugini, D., Dingwell, D.B., 2006. “Explosive energy” during volcanic eruptions from fractal analysis of pyroclasts. Earth Planet. Sci. Lett. 248 (3), 800-807.

Lorenz, V., 1973. On the formation of maars. Bull. Volcanol. 37 (2), 183-204.

Lorenz, V., 1975. Formation of phreatomagmatic maar-diatreme volcanoes and its relevance to kimberlite diatremes. Phys. Chem. Earth 9, 17-27.

Lorenz, V., 2003. Maar-diatreme volcanoes, their formation, and their setting in hard-rock or soft-rock environments. Geologija $15,72-83$.

Lovejoy, S., Schertzer, D., 2007. Scaling and multifractal fields in the solid earth and topography. Nonlinear Process. Geophys. 14 (4), 465-502.

Mandelbrot, B.B., 1967. How long is the coast of Britain? Statistical self-similarity and fractional dimension. Science 156 (3775), 636-638.

Maria, A., Carey, S., 2002. Using fractal analysis to quantitatively characterize the shapes of volcanic particles. 107 (B11), 1978-2012 (ECV-7).

Maria, A., Carey, S., 2007. Quantitative discrimination of magma fragmentation and pyroclastic transport processes using the fractal spectrum technique. J. Volcanol. Geotherm. Res. $161(3), 234-246$

Mattsson, H.B., 2010. Textural variation in juvenile pyroclasts from an emergent, Surtseyan-type, volcanic eruption: the Capelas tuff cone, São Miguel (Azores). J. Volcanol. Geotherm. Res. 189 (1), 81-91.

Mertes, H., Schmincke, H.U., 1985. Mafic potassic lavas of the Quaternary West Eifel volcanic field. Contrib. Mineral. Petrol. 89 (4), 330-345.

Meyer, W., 2013. Geologie der Eifel. Schweizerbart, Stuttgart (614 pp.).

Meyer, W., Stets, J., 1979. Die Manderscheider Vulkangruppe (Westeifel) in Beziehung zu den Strukturen des Sockels. Z. Dtsch. Geol. Ges. 130, 273-288.

Mitchell, R.H., 1986. Kimberlite magmatism and textural genetic classifications of kimberlite. Kimberlites. Springer, US, pp. 29-71.

Mysen, B.O., Arculus, R.J., Eggler, D.H., 1975. Solubility of carbon dioxide in melts of andesite, tholeiite, and olivine nephelinite composition to $30 \mathrm{kbar}$ pressure. Contrib. Mineral. Petrol. 53 (4), 227-239.

Nakamura, K., Krämer, F., 1970. Basaltic ash flow deposits from a maar in West-Eifel. Neues Jahrbuch für Geologie und Paläontologie. Monatshefte, Germany, pp. 491-501.

Orford, J.D., Whalley, W.B., 1983. The use of the fractal dimension to quantify the morphology of irregular-shaped particles. Sedimentology 30 (5), 655-668.
Pepe, S., Solaro, G., Ricciardi, G.P., Tizzani, P. 2008. On the fractal dimension of the fallout deposits: a case study of the 79 AD Plinian eruption at Mt. Vesuvius. J. Volcanol. Geotherm. Res. 177 (1), 288-299.

Perugini, D., Valentini, L., Poli, G., 2007. Insights into magma chamber processes from the analysis of size distribution of enclaves in lava flows: a case study from Vulcano Island (Southern Italy). J. Volcanol. Geotherm. Res. 166 (3), 193-203.

Perugini, D., Speziali, A., Caricchi, L., Kueppers, U., 2011. Application of fractal fragmentation theory to natural pyroclastic deposits: insights into volcanic explosivity of the Valentano scoria cone (Italy). J. Volcanol. Geotherm. Res. 202 (3), 200-210.

Rausch, J., 2014. Eifel maars: external water vs. magmatic volatiles (Eifel Volcanic Field, Germany). (PhD Thesis) University of Fribourg, Switzerland.

Ross, P.S., Delpit, S., Haller, M.J., Németh, K., Corbella, H., 2011. Influence of the substrate on maar-diatreme volcanoes-an example of a mixed setting from the Pali Aike volcanic field, Argentina. J. Volcanol. Geotherm. Res. 201 (1), 253-271.

Schaber, K., Sirocko, F., 2005. Lithologie und Stratigraphie der spätpleistozänen Trockenmaare der Eifel. Mainz. Geowiss. Mitt. 33, 295-340.

Schmincke, H.U., 1977. Phreatomagmatische Phasen in quartären Vulkanen der Osteifel. Geol. Jahrb. 39, 3-45.

Schmincke, H.U., 2007. The Quaternary volcanic fields of the East and West Eifel (Germany). In: Ritter, J.R., Christensen, U.R. (Eds.), Mantle Plumes 24. Springer, Berlin Heidelberg (241-322 pp.).

Schmincke, H.U., 2009. Vulkane der Eifel: Aufbau, Entstehung und heutige Bedeutung. Spectrum, Heidelberg (160 pp.).

Schmincke, H.U., Fisher, R.V., Waters, A.C., 1973. Antidune and chute and pool structures in the base surge deposits of the Laacher See area, Germany. Sedimentology 20 (4), 553-574.

Sirocko, F., Dietrich, S., Veres, D., Grootes, P.M., Schaber-Mohr, K., Seelos, K., Nadeau, M.J., Kromer, B., Rothacker, L., Röhner, M., Krbetschek, M., Appleby, P., Hambach, U., Rolf, C., Sudo, M., Grim, S., 2013. Multi-proxy dating of Holocene maar lakes and Pleistocene dry maar sediments in the Eifel, Germany. Quat. Sci. Rev. 62, 56-76.

Smith Jr., T.G., Marks, W.B., Lange, G.D., Sheriff Jr., W.H., Neale, E.A., 1989. A fractal analysis of cell images. J. Neurosci. Methods 27 (2), 173-180.

Smith Jr., T.G., Lange, G.D., Marks, W.B., 1996. Fractal methods and results in cellular morphology-dimensions, lacunarity and multifractals. J. Neurosci. Methods 69 (2), 123-136.

Steininger, J., 1820. Die erloschenen Vulkane in der Eifel und am Niederrheine: Ein Bericht an die Gesellschaft nützlicher Forschungen zu Trier. Florian Kupferberg, Mainz, pp. 1-180.

Sun, W., Xu, G., Gong, P., Liang, S., 2006. Fractal analysis of remotely sensed images: a review of methods and applications. Int. J. Remote Sens. 27 (22), 4963-4990.

van den Bogaard, P., 1995. ${ }^{40} \mathrm{Ar} /{ }^{39} \mathrm{Ar}$ ages of sanidine phenocrysts from Laacher See Tephra (12,900 yr BP): chronostratigraphic and petrological significance. Earth Planet. Sci. Lett. 133 (1), 163-174.

Vonlanthen, P., Rausch, J., Ketcham, R.A., Putlitz, B., Baumgartner, L.P., Grobety, B., 2014 High-resolution 3D analyses of the shape and internal constituents of small volcanic ash particles: the contribution of SEM micro-computed tomography (SEM micro-CT). J. Volcanol. Geotherm. Res. http://dx.doi.org/10.1016/j.jvolgeores.2014.11.016.

Waters, A.C., Fisher, R.V., 1971. Base surges and their deposits: Capelinhos and Taal volcanoes. J. Geophys. Res. 76 (23), 5596-5614.

Wohletz, K.H., 1983. Mechanisms of hydrovolcanic pyroclast formation: grain-size, scanning electron microscopy, and experimental studies. J. Volcanol. Geotherm. Res. 17 (1), 31-63.

Wyllie, P.J., 1979. Magmas and volatile components. Am. Mineral. 64 (5-6), 469-500.

Zimanowski, B., Fröhlich, G., Lorenz, V., 1991. Quantitative experiments on phreatomagmatic explosions. J. Volcanol. Geotherm. Res. 48 (3), 341-358.

Zimanowski, B., Büttner, R., Lorenz, V., 1997. Premixing of magma and water in MFCI experiments. Bull. Volcanol. 58 (6), 491-495.

Zolitschka, B., Negendank, J.F.W., Lottermoser, B.G., 1995. Sedimentological proof and dating of the early Holocene volcanic eruption of Ulmener Maar (Vulkaneifel, Germany). Int. J. Earth Sci. 84 (1), 213-219.

Zöller, L., Blanchard, H., McCammon, C., 2009. Can temperature assisted hydrostatic pressure reset the ambient TL of rocks? A note on the TL of partially heated country rock from volcanic eruptions. Ancient TL 27 (1), 15-23. 